\title{
Channel Maintenance and Flushing Flows for the Klamath River Below Iron Gate Dam, California
}

By Christopher L. Holmquist-Johnson and Robert T. Milhous

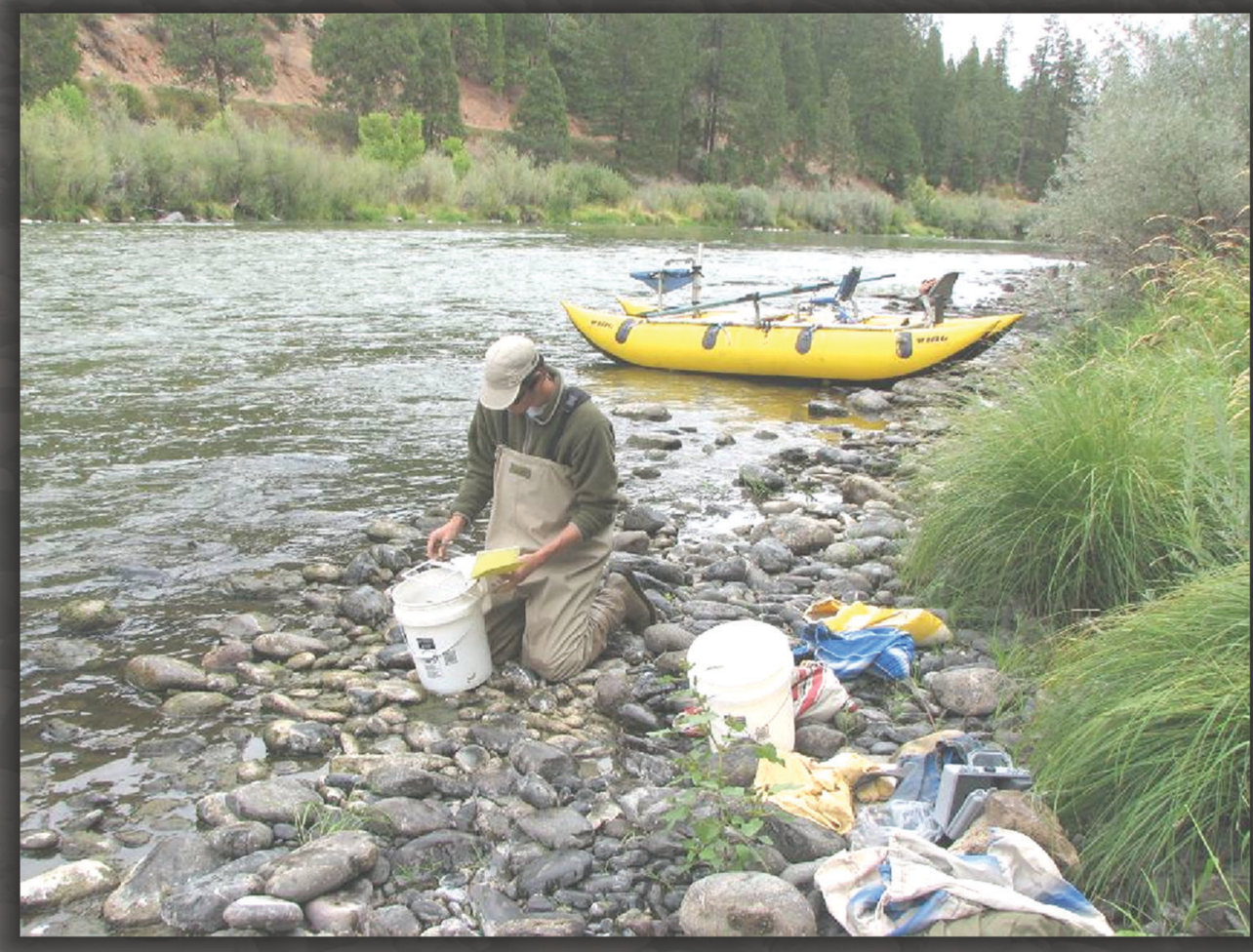

Open-File Report 2010-1086 


\title{
U.S. Department of the Interior KEN SALAZAR, Secretary
}

\author{
U.S. Geological Survey \\ Marcia K. McNutt, Director
}

For product and ordering information:

World Wide Web: http://www.usgs.gov/pubprod

Telephone: 1-888-ASK-USGS

For more information on the USGS—-the Federal source for science about the Earth, its natural and living resources, natural hazards, and the environment:

World Wide Web: http://www.usgs.gov

Telephone: 1-888-ASK-USGS

Suggested citation:

Holmquist-Johnson, C.L., and Milhous, R.T., 2010, Channel maintenance and flushing flows for the Klamath River below Iron Gate Dam, California: U.S. Geological Survey Open File Report 2010-1086, $31 \mathrm{p}$.

Any use of trade, product, or firm names is for descriptive purposes only and does not imply endorsement by the U.S. Government.

Although this report is in the public domain, permission must be secured from the individual copyright owners to reproduce any copyrighted material contained within this report. 


\section{Contents}

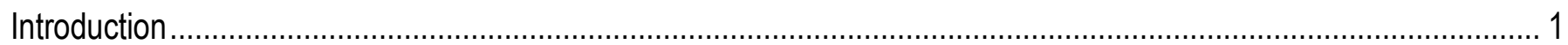

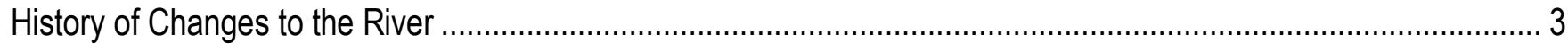

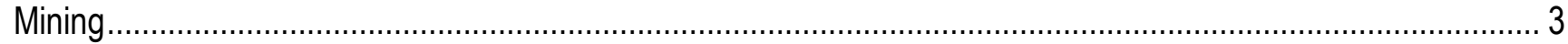

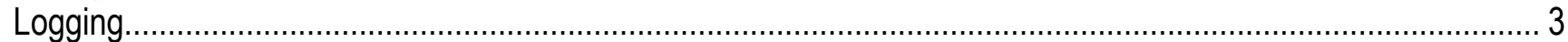

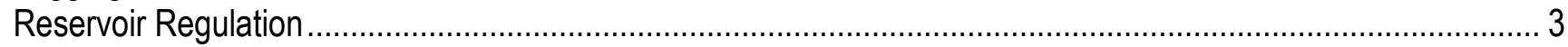

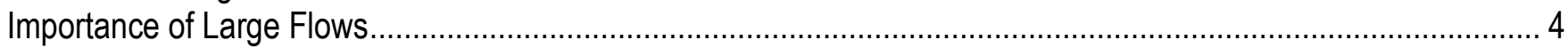

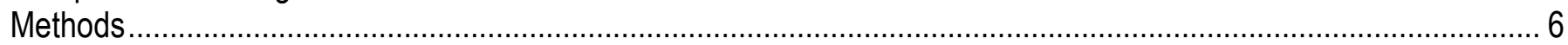

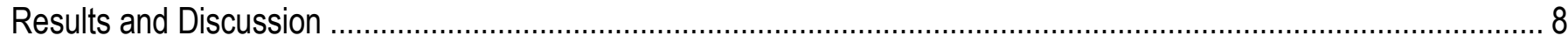

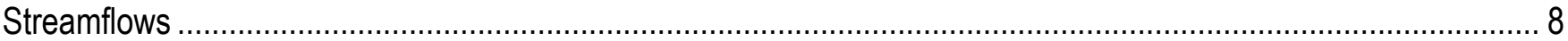

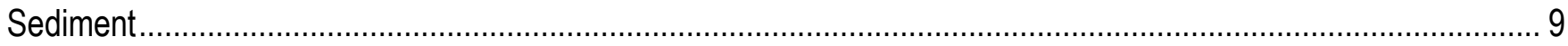

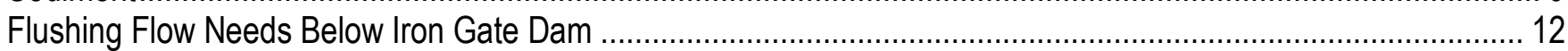

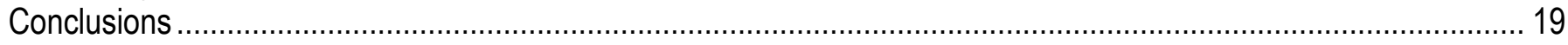

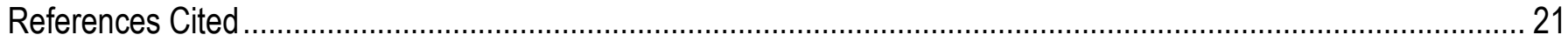

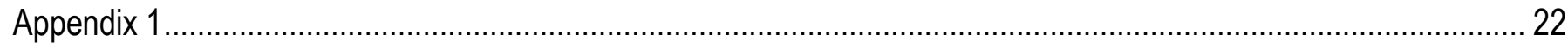

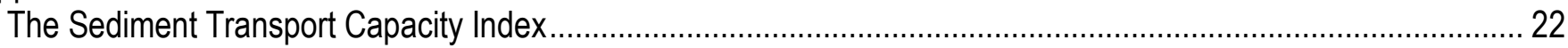

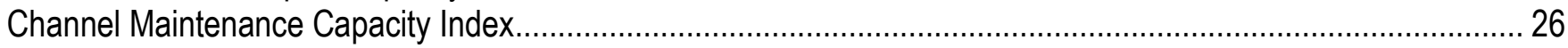

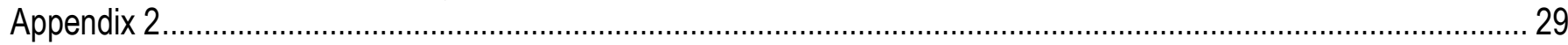

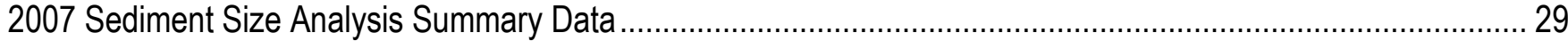




\section{Figures}

1. Klamath River Basin, Oregon and California ......................................................................................... 2

2. Historical daily average discharge for the Klamath River below Iron Gate Dam, California ................................. 5

3. Average discharge in the Klamath River near Iron Gate Dam for each day in a water year................................. 8

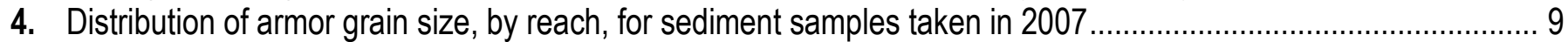

5. Distribution of substrate grain size, by reach, for sediment samples taken in 2007 ......................................... 10

6. Distribution of average grain size for sediment samples taken in 2007 below Iron Gate Dam ............................ 11

7. The dimensionless shear stress of the Klamath River below Iron Gate Dam calculated using the

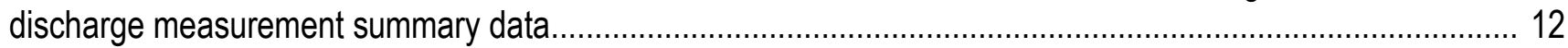

8. The armor shear stress ratio of the Klamath River below Iron Gate Dam …….............................................. 14

9. The average armor and substrate shear stress ratio of the Klamath River below Iron Gate Dam........................ 15

10. Annual sediment transport capacity index for the Klamath River below Iron Gate Dam, California ..................... 16

11. Annual channel maintenance capacity index for the Klamath River below Iron Gate Dam, California ................. 17

12. Number of days each water year during which streamflows were adequate to keep sediment out of the substrate or remove fines from the substrate

13. Streamflow requirements to keep sediment out of the substrate or remove fines from the substrate on the Klamath River below Iron Gate Dam.

14. Measured concentrations of suspended sediment in the Klamath River near Orleans, California, as related to the discharge in the river

15. Measured total sediment load in the Klamath River near Orleans, California, as related to the discharge in the river

16. Annual sediment transport index for the Klamath River at Orleans, California................................................. 25

17. Annual channel maintenance capacity index for the Klamath River at Orleans, California ....

\section{Tables}

1. Hydrologic features of the Klamath River Basin, California. The maximum discharge is the maximum instantaneous discharge for the December 1964 flood

2. Sediment grade scale using the American Geophysical Union sediment classification system and sediment types consisting of the armor, substrate, and fines in the stream ....

3. The dimensionless shear stress and discharges used to calculate the number of days the substrate is flushed of fines or moved and the number of days the substrate is stable

4. Comparison of Ayres and Associates and U.S. Geological Survey estimated streamflows needed to flush fine sediment in the Klamath River below Iron Gate Dam

5. Armor grain size analysis for sediment samples collected for six study sites below Iron Gate Dam .................... 29

6. Substrate grain size analysis for sediment samples collected for six study sites below Iron Gate Dam............ 29

7. Fines grain size analysis for sediment samples collected for six study sites below Iron Gate Dam 


\section{Conversion Factors}

Inch/Pound to SI

\begin{tabular}{|c|c|c|}
\hline Multiply & By & To obtain \\
\hline \multicolumn{3}{|c|}{ Length } \\
\hline inch (in.) & 2.54 & centimeter $(\mathrm{cm})$ \\
\hline inch (in.) & 25.4 & millimeter $(\mathrm{mm})$ \\
\hline foot $(\mathrm{ft})$ & 0.3048 & meter $(\mathrm{m})$ \\
\hline mile (mi) & 1.609 & kilometer $(\mathrm{km})$ \\
\hline \multicolumn{3}{|c|}{ Area } \\
\hline acre & 0.4047 & hectare (ha) \\
\hline square foot $\left(\mathrm{ft}^{2}\right)$ & 929.0 & square centimeter $\left(\mathrm{cm}^{2}\right)$ \\
\hline square foot $\left(\mathrm{ft}^{2}\right)$ & 0.09290 & square meter $\left(\mathrm{m}^{2}\right)$ \\
\hline square inch $\left(\right.$ in $\left.^{2}\right)$ & 6.452 & square centimeter $\left(\mathrm{cm}^{2}\right)$ \\
\hline \multicolumn{3}{|c|}{ Volume } \\
\hline gallon (gal) & 0.003785 & cubic meter $\left(\mathrm{m}^{3}\right)$ \\
\hline million gallons (Mgal) & 3,785 & cubic meter $\left(\mathrm{m}^{3}\right)$ \\
\hline cubic foot $\left(\mathrm{ft}^{3}\right)$ & 0.02832 & cubic meter $\left(\mathrm{m}^{3}\right)$ \\
\hline acre-foot (acre-ft) & 1,233 & cubic meter $\left(\mathrm{m}^{3}\right)$ \\
\hline \multicolumn{3}{|c|}{ Flow rate } \\
\hline acre-foot per day (acre-ft/d) & 0.01427 & cubic meter per second $\left(\mathrm{m}^{3} / \mathrm{s}\right)$ \\
\hline acre-foot per year (acre-ft/yr) & 1,233 & cubic meter per year $\left(\mathrm{m}^{3} / \mathrm{yr}\right)$ \\
\hline foot per second ( $\mathrm{ft} / \mathrm{s})$ & 0.3048 & meter per second $(\mathrm{m} / \mathrm{s})$ \\
\hline cubic foot per second $\left(\mathrm{ft}^{3} / \mathrm{s}\right)$ & 0.02832 & cubic meter per second $\left(\mathrm{m}^{3} / \mathrm{s}\right)$ \\
\hline million gallons per day (Mgal/d) & 0.04381 & cubic meter per second $\left(\mathrm{m}^{3} / \mathrm{s}\right)$ \\
\hline mile per hour (mi/h) & 1.609 & kilometer per hour $(\mathrm{km} / \mathrm{h})$ \\
\hline
\end{tabular}




\title{
Channel Maintenance and Flushing Flows for the Klamath River Below Iron Gate Dam
}

\author{
By Christopher L. Holmquist-Johnson and Robert T. Milhous
}

\section{Introduction}

The Klamath River is a major river in northern California and southern Oregon. Iron Gate Dam divides the river into the two subunits where there is a significant change in utilization of the river. Upstream of Iron Gate Dam, the Klamath River is heavily used for irrigation around Upper Klamath Lake. The river between the lake and Iron Gate Dam has a number of hydropower facilities, some of which are used for peaking power production. Iron Gate Reservoir reregulates the river below the Copco Dam hydropeaking facilities. Recreation also is important above Iron Gate Dam. Downstream of Iron Gate Dam, the river is very important for the propagation of salmon.

Past activities in the watershed have had an affect on the channel of the Klamath River and on sediment loads. Some of the major affects have been: (1) mining, (2) logging, and (3) reservoir regulation. The objectives of this paper are: (1) to present an introduction to the flow and sediment dynamics of the river and (2) to show how flushing flows are important to the aquatic ecosystem, particularly the sustainability of the salmon fishery.

The Klamath River Basin is located in northern California and southern Oregon in a region of complex landforms (Figure 1). Only the part of the basin below Iron Gate Dam on the Klamath River is considered in this study. To address concerns relating to substrate conditions in the mainstem Klamath River, the Arcata, California, office of the U.S. Fish and Wildlife Service contracted with the U.S. Geological Survey (USGS) to determine flushing flows required to improve and maintain quality spawning and rearing habitats for salmon, and to reduce the abundance of preferred habitats of the polychaete worm suspected of being the intermediate host for Ceratomyxa shasta, a species of bacteria that infects fish. The limited funding provided by the U.S. Fish and Wildlife Service was utilized for a single field reconnansiance in which eighteen sediment samples (three samples per reach) were collected and analyzed for the six sub-reaches below Iron Gate Dam identified in the 1999 Ayres and Associates report. In conducting this analysis, USGS relied on existing 1-D HEC-RAS (U.S. Army Corps of Engineers, 2006) transect data collected by Ayres and Associates (1999). Details regarding the transect data and model calibration are provided in the Ayres and Assocaites report. Three major factors important to studying channel maintenance flows and aquatic habitat for the Klamath River below Iron Gate Reservoir include:

1. the history of anthropogenic changes to the river that have affected the aquatic habitat quality,

2. the importance of large flows on the riverine environment, and

3. the flows needed to flush fine sediment and discharge requirements to mobilize the sediment (armor and substrate) contained in the riverbed downstream of Iron Gate Dam. 


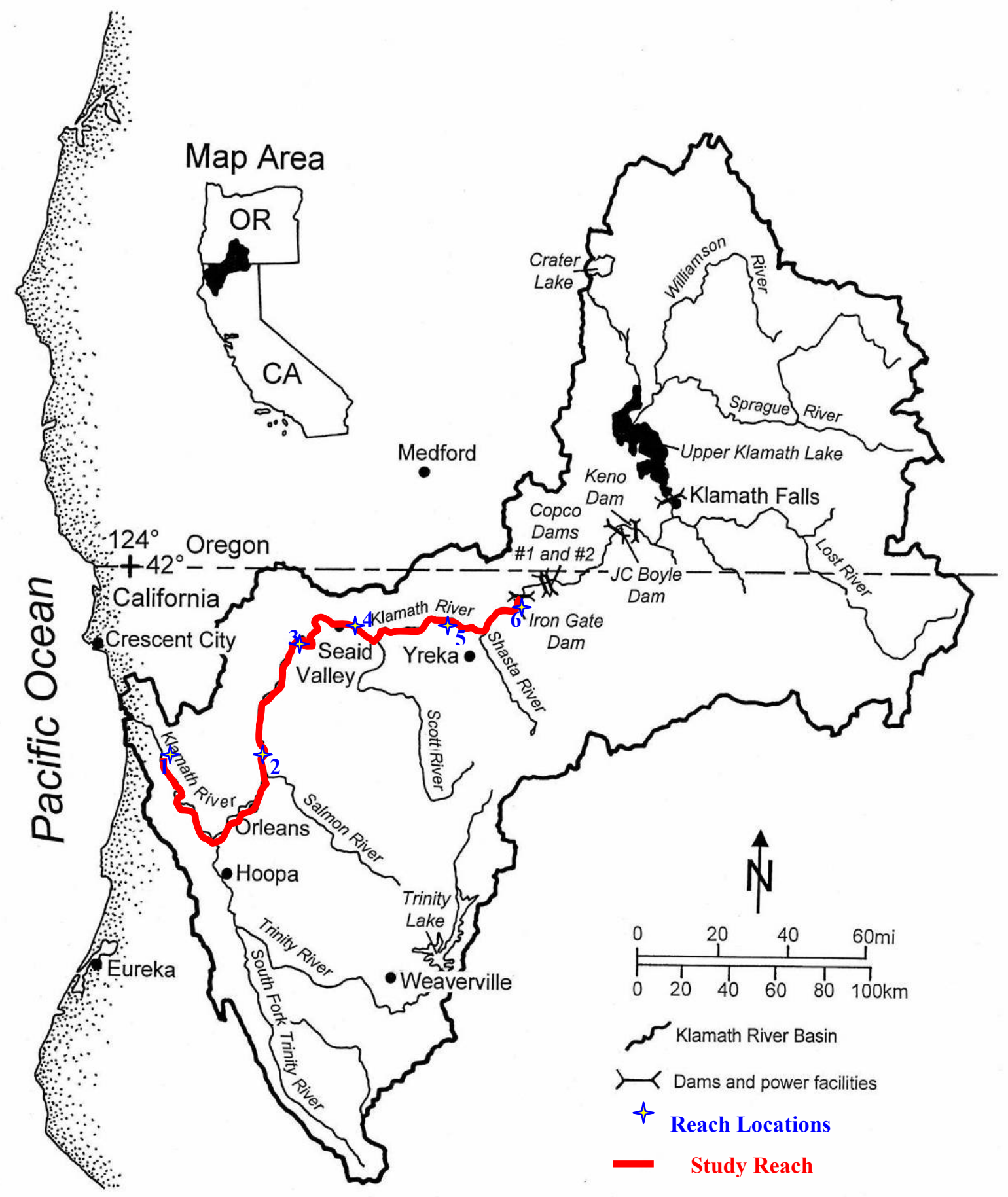

Figure 1. Klamath River Basin, Oregon and California. 


\section{History of Changes to the River}

Major anthropogenic disturbances affecting the Klamath River below Iron Gate Reservoir include: (1) gold mining, (2) changes in land use, (an important effect is logging), and (3) regulation of the river by upstream reservoirs.

Mining

Gold was discovered in the Klamath River Basin in 1849. It was mined from the streambed, river bars, floodplain, and terraces along the river, with most of the mining effects occurring between Weitchpec, which is near the confluence of the Klamath and Trinity Rivers, and Cottonwood Creek, which is upstream from the confluence of the Shasta and Klamath Rivers. The tributaries of the river also were mined (Ayres and Associates, 1999). Placer mining of the river continues on a small scale to this day.

Ayres and Associates (1999) compared the effects of mining in the Klamath River watershed and made the following statement:

"...the extent of mining debris does not appear to have been sufficient to overwhelm most of the streams and rivers of the Klamath River watershed. There are no significant or mapped fluvially deposited mining debris sediments along the mainstem Klamath River similar to those found along the streams and rivers issuing from the Sierras. There are some areas where terrace and floodplain deposits may be overlain by a minor thickness of mining debris sediment or small areas where mining debris deposits had accumulated and are presently protected from erosion."

The following statement is also made in the Ayres and Associates (1999) report:

“...past mining activities continue, in places, to exert some control on existing fish habitat. Although past gold mining activates had numerous impacts on the characteristics and morphology of the Klamath River and its tributaries, many of these impacts were short-lived and temporary. The remaining influences of these disturbances are in the form of changes in channel and floodplain geometry as seen in the relict pools, bars, and tailing piles."

This mining has a localized effect on the river but appears not to be of major concern for the fishery resources at the present time.

Logging

Logging of the Klamath River watershed is a major contributor of sediment to the Klamath River. The short- and long-term cumulative effect of logging on the fisheries resources is of great concern. The Klamath River Basin Fisheries Task Force report (1991) and Anglin (1994) indicate that logging has contributed sediment to the Klamath River. The effects of this sedimentation are: (1) filling voids in the substrate with fines, (2) deposition of fines in pools, and (3) deposition of deltas at the mouths of tributaries. Anglin (1994) reports that sediment transported to the Klamath River below Iron Gate Dam has resulted in delta deposition at tributary mouths, where the streamflow passes under the sediment surface, at times creating a significant barrier to salmon migration.

\section{Reservoir Regulation}

Flows in the Klamath River below Iron Gate Dam reflect the combined effects of all the major dams on the Klamath River. Prior to the construction of Iron Gate Dam in 1961 as a re-regulating reservoir, Copco was operated for peaking power. After Iron Gate Dam was constructed, the system has 
been operated to maintain minimum flows with a typical stepped rule patter with minimum discharges much higher than what was maintained prior to Iron Gate Dam. A plot of the peak discharges for the Klamath River near Iron Gate Dam suggests that peak discharges increased significantly in magnitude and frequency following the installation of Iron Gate Dam (Figure 2). However, Ayres and Associates (1999) note that the increase in magnitude and frequency of the peak discharges may be tied to the increase in urbanization and agriculture in the watershed and the natural variation in hydrology (wet compared to dry time periods). For example, the early part of the century which was a wet period was followed by a very dry period in the early 1930s. By 1950, annual runoff increased to levels that were often greater than those in the early 1900s. Annual runoff fluctuated between 1 and 2.5 million acrefeet from 1960 to 1990, but dropped to its lowest recorded levels in 1992 and 1994 (Ayres and Associates, 1999). The more recent drop in annual runoff (2008 to current) is the result of drought conditions compounded by irrigation diversions and reduced base flows in the upper watershed. It is these extended drought/low flow periods that have a significant impact on the sediment transport, flushing flow requirements, and channel bed paving downstream of Iron Gate Dam.

In its 1991 report, the Klamath River Basin Fisheries Task Force (1991) made the following statement:

"Even before Iron Gate Dam, the spawning gravels below Copco Dam were observed by CDFG [California Department of Fish and Game] to be "cemented" with silt as far as the mouth of the Scott River and too compacted for the smaller salmon of the Klamath River to construct redds (Wales 1950). The same problem was observed after Iron Gate in the 1970s and 1980s. In addition, rooted aquatic vegetation was able to take hold, creating slower pockets of water where silt had deposited."

The sources of fine sediment may be from logging, mining, or other factors (including natural), but it is the streamflows that affect the movement of fines in the river.

\section{Importance of Large Flows}

The streamflows in the Klamath River Basin are quite variable from day to day and year to year. The drainage areas and annual discharges at four locations in the Klamath watershed are given in Table 1. A major storm (Figure 2) in northern California in December 1964 (water year 1965) had a major effect on the Klamath River watershed. The 1964 flood produced the largest recorded flows in the Klamath River below Iron Gate Dam. It is these high flows that rework the channel by removing the armor layer, reshaping the channel, and, thus, providing new habitat for fish.

Ayers and Associates (1999) and Hardy and Addley (2001) indicate that flows from Iron Gate Dam have been adequate for channel maintenance in most years. Fine sediments regularly are flushed from riffles and pools during average water years and under normal flow conditions (Ayers and Associates, 1999). However, low flows over sustained drought periods result in greater deposition of fine sediments and, thus, adverse changes to channel features. Lack of flows sufficient to mobilize alluvial features has lead to increased siltation of pools and riffles, allowing rooted aquatic vegetation to become established. This creates hydraulic conditions that are conducive to further accumulation of fine sediments (Klamath River Basin Fisheries Task Force, 1991), thereby exacerbating the problem. Flows

of the magnitude necessary to transport accumulated fine sediments typically are much lower than those necessary to maintain functioning geomorphic features that may be adversely affected under current project dam operations, at least downstream to the Shasta River (PacifiCorp, 2004). While there is conflicting information regarding the extent of effects that dam operations have had on the 
geomorphology of the river below Iron Gate Dam, geomorphic features important to aquatic organisms have been degraded because of fine-sediment accumulations and establishment of dense beds of rooted aquatic macrophytes. These macrophyte beds are the primary habitats for the polychaete worm that serve as the intermediate host for known salmonid parasites in the Klamath River (Stocking and others, 2006).

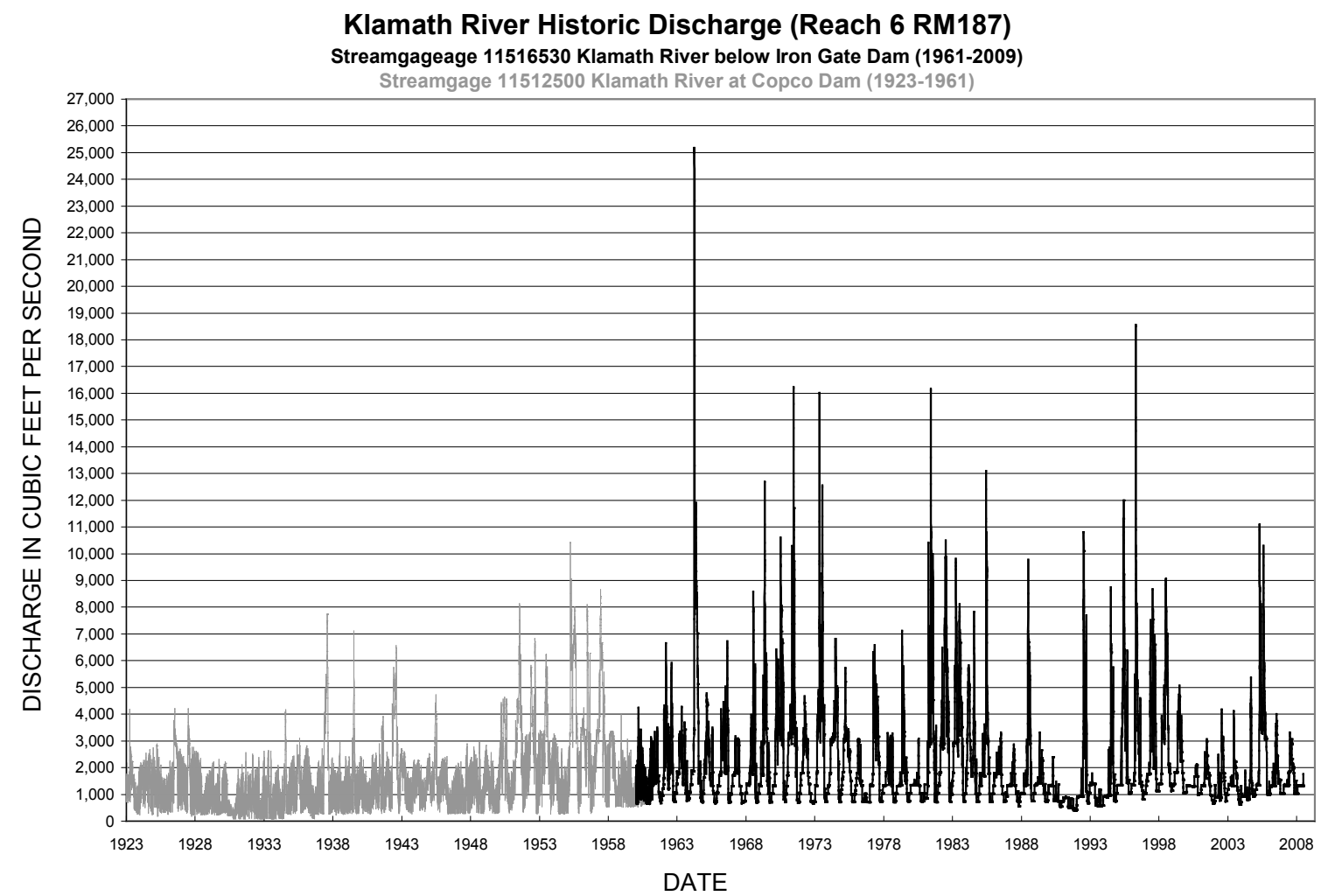

Figure 2. Historical daily average discharge for the Klamath River below Iron Gate Dam, California.

Table 1. Hydrologic features of the Klamath River Basin, California. The maximum discharge is the maximum instantaneous discharge for the December 1964 flood.

\begin{tabular}{|c|c|c|c|c|c|}
\hline Klamath River & $\begin{array}{l}\text { Drainage Area } \\
\qquad\left(\mathrm{mi}^{2}\right)\end{array}$ & $\begin{array}{l}\text { Average annual } \\
\text { discharge } \\
\left(\mathrm{ft}^{3} / \mathrm{s}\right)\end{array}$ & $\begin{array}{l}\text { Average annual } \\
\text { volume of water } \\
\text { (million acre-ft) }\end{array}$ & $\begin{array}{c}\text { Maximum } \\
\text { discharge } \\
\left(\mathrm{ft}^{3} / \mathrm{s}\right)\end{array}$ & Period of record \\
\hline at Copco Dam & 4,370 & 1,803 & 1.31 & 12,000 & 1924-1961 \\
\hline below Iron Gate Dam & 4,630 & 2,060 & 1.49 & 29,400 & 1961-current \\
\hline at Orleans & 8,475 & 8,163 & 5.91 & 307,000 & 1927 \\
\hline Trinity River & 2,853 & 4,904 & 3.55 & 227,814 & 1911-current \\
\hline at Klamath & 12,100 & 17,430 & 12.63 & 557,000 & 1950-current \\
\hline
\end{tabular}

$\left[\mathrm{mi}^{2}\right.$, square miles, $\mathrm{ft}^{3} / \mathrm{s}$, cubic feet per second; acre-feet $]$ 


\section{Methods}

The bed material in a gravel or cobble bed river has three components that are of interest in evaluating sediment-flushing flows and the quality of the riverbed material for spawning, egg incubation, and fry emergence (Sutton and Milhous, 2008). These components (surface fines, substrate, and armor) were sampled at multiple locations within each of the six study sites on the Klamath River corresponding to the reach locations identified by Ayers and Associates (1999) so that the existing cross-section data could be used in analyzing the flow required to flush away the fines and mobilize the substrate within each of the six identified reaches. Multiple samples collected within each reach were combined to generate an average grain-size distribution for each of the six study sites.

In the summer 2007, Wolman pebble counts (Wolman, 1954) were conducted and sediment samples were collected to describe the size distribution of the bed-surface material (armor), the sediment below the armor, and fines and sand above the armor from Iron Gate Dam (RM187) downstream to the confluence of Blue Creek (RM16, Figure 1). Bed material (substrate and fines) was drysieved and weighed in the laboratory. The sieve sizes used for bed-material analysis ranged from 0.063 to $512 \mathrm{~mm}$. Sediment-grade scales were defined using the American Geophysical Union sediment classification system as follows:

Table 2. Sediment grade scale using the American Geophysical Union sediment classification system and sediment types consisting of the armor, substrate, and fines in the stream.

\begin{tabular}{lcccc}
\hline Sediment Type & $\begin{array}{c}\text { Grain size } \\
\text { (millimeter) }\end{array}$ & Armor & $\begin{array}{c}\text { Sediment classification range } \\
\text { Substrate }\end{array}$ & Fines \\
\hline Silt/clay & $<0.062$ & & & \\
Sand & $0.062-2$ & & \\
Gravel & $2-64$ & & \\
Cobble & $64-250$ & & & \\
Boulder & $250-512$ & & & \\
\hline
\end{tabular}

The techniques used in sampling the bed material are presented in Milhous and others (1995). There was one exception. In some locations, the armor was sampled by placing a 55-gallon barrel with its ends removed on the streambed surface, sampling the particles within the barrel, and measuring the size of the particles. The barrel provides an isolated sampling volume from the rushing river water and was moved until at least 100 particles were measured at each sample location. The size distribution was determined from the measurements and modified to the equivalent of a Wolman (1954) count using the techniques of Kellerhals and Bray (1971). A summery of the 2007 sediment size analysis data is provided in Appendix 2.

Data measured at the streamgage on the Klamath River below Iron Gate Dam were used to calculate dimensionless shear stress (equation 1). The 50-percent relation was used to determine the discharge associated with different levels of substrate movement:

$$
\beta=\frac{n^{2} v^{2}}{1.492^{2} d^{1 / 3}(G-1) D_{50}}
$$

where

$\beta=$ dimensionless shear stress,

$n=$ Manning's roughness, 
$v=$ channel velocity in feet per second,

$d=$ average flow depth in feet,

$G=$ specific gravity of sediment, and

$D_{50}=$ median grain size in feet.

Using the cross-sectional survey data from Ayres and Associates (1999), a one-dimensional hydraulic model, HEC-RAS (U.S. Army Corps of Engineers, 2006), was used to calculate channel shear stress within each of the six reaches for a range of discharges $\left(1,000-50,000 \mathrm{ft}^{3} / \mathrm{s}\right)$. Based on the sediment samples collected in 2007, critical shear stress $\left(\tau_{c}\right)$ values were determined based on the average grain size distribution within each reach using the following equation:

$$
\tau_{c}=k\left(\gamma_{s}-\gamma_{w}\right) D_{s}
$$

where

$k=$ dimensionless critical shear stress ( $\mathrm{k} \sim 0.045$ Knighton, 1998),

$\gamma_{\mathrm{s}}=$ specific weight of the sediment,

$\gamma_{\mathrm{w}}=$ specific weight of water, and

$D_{\mathrm{s}}=$ grain size of interest in meters.

To determine the discharge associated with different levels of substrate movement within each reach, the results of the hydraulic model were used to calculate the ratio of the bed shear stress $\left(\tau_{0}\right)$ at a specific discharge to critical shear stress (equation 3).

$$
\frac{\tau_{o}}{\tau_{c}}=\frac{\gamma_{w} R S}{k\left(\gamma_{s}-\gamma_{w}\right) D_{s}}
$$

An immobile bed occurs where there is absolutely no movement of the substrate. Any suspended sediment that comes near the bed will be absorbed into the voids of the gravel until the voids are full. A stable bed is defined as one where the substrate has no chance of moving but sediment in the water column may not be absorbed into the streambed. A flushing flow occurs when some of the substrate is moved. The longer the duration of the flow, the more fine sediment and sand will be flushed from the substrate. We define movement as disturbance of surface materials of more than 20-30 percent of the bed at any given time. As the streamflow increases, more of the substrate is in motion. It is rare for the whole bed to be in motion at one time.

An index of a river's ability to transport sediment (flushing flows) is formed by dividing the sediment load at a given discharge by the load at a reference discharge (Milhous, 1995). The sediment transport capacity index (stci) is given in equation 4 and described in more detail in Appendix 1:

$$
s t c i=\frac{\left(Q-Q_{c r t}\right)^{d} Q}{Q_{r e f}^{d+1}}
$$

where

$Q=$ the daily discharge,

$Q_{\text {crt }}=$ the minimum discharge required for flushing, and

$Q_{\text {ref }}=$ a reference discharge (arbitrarily selected by the user) to make stci dimensionless.

The sum of all days within a water year provides the annual sediment transport capacity index (ASTCI) where $\mathrm{Q}>\mathrm{Q}_{\mathrm{crt}}$. 


\section{Results and Discussion}

\section{Streamflows}

The maximum daily discharge at Copco Dam for the 37 years prior to completion of Iron Gate Dam (1961) was $12,000 \mathrm{ft}^{3} / \mathrm{s}$ and occurred on December 21, 1955. The maximum daily discharge for the 48 years post-completion of Iron Gate Dam, as measured below the dam, was $25,000 \mathrm{ft}^{3} / \mathrm{s}$ and occurred on December 22, 1964. The average of the daily discharges for the Klamath River below Iron Gate Dam is presented in Figure 3. From Figure 3 it is evident that there are two periods of significant runoff in the basin: (1) the winter months of December and February (days 62-152) and (2) the spring runoff (snowmelt) between mid-March and mid-May (days 166-227). The winter months are when most floods of significance occur. As a result of Iron Gate Dam, the average daily discharge has been modified from pre-dam conditions. Figure 3 shows how the hydrograph has been reshaped, resulting in higher flows from December to May (winter and spring) and lower flows from June to mid-October (summer and fall).

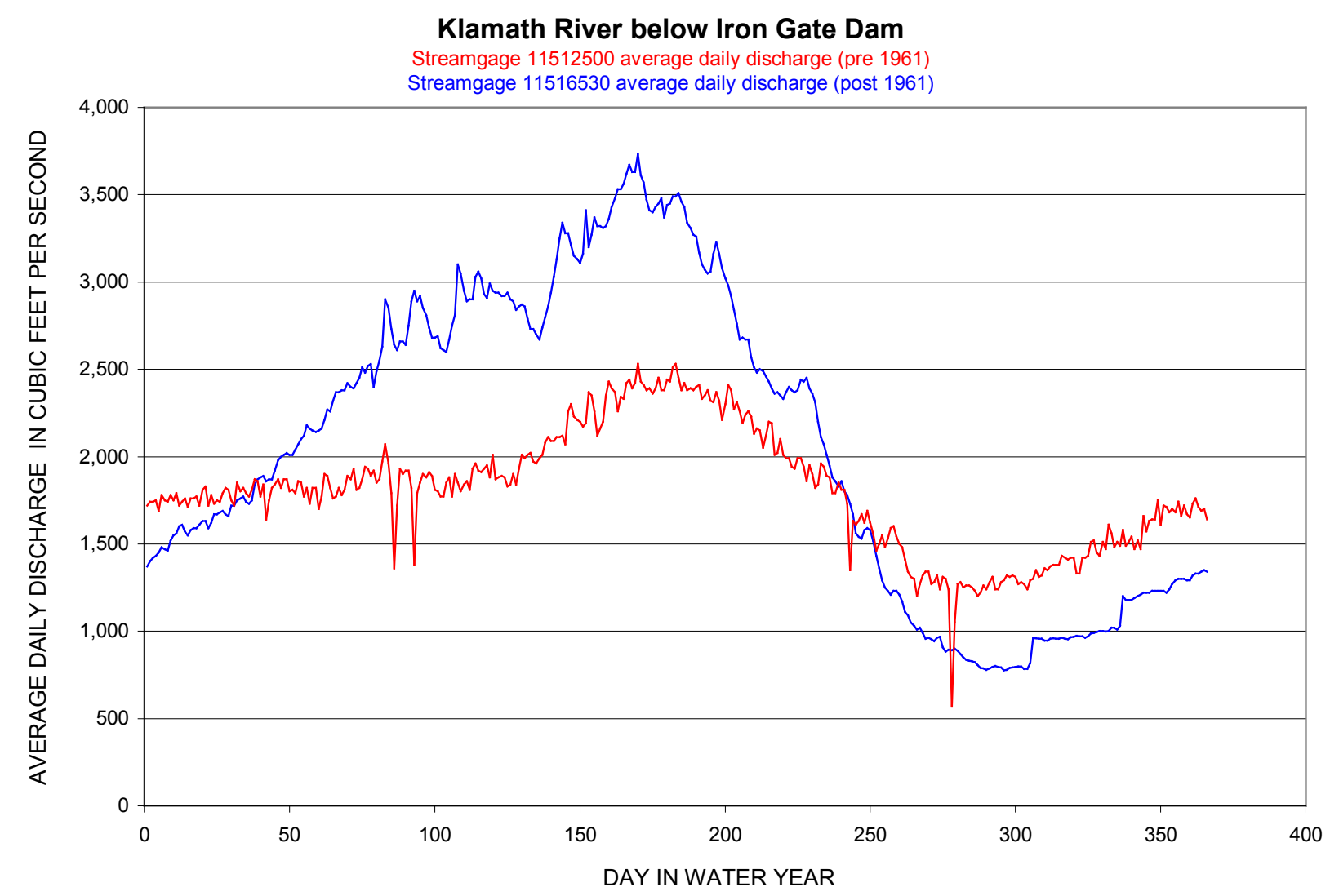

Figure 3. Average discharge in the Klamath River near Iron Gate Dam before and after 1961 (when Iron Gate Dam was completed) for each day in a water year. The first day of a water year is October 1 . The data are for a 365-day year (February 29 data not included). The four days on which discharges registered below the general trend were national holidays (day $86=$ Christmas Day, day $93=$ New Years Day, day $242=$ Memorial Day, and $277=$ Independence Day). 


\section{Sediment}

The particle size distributions for armor and substrate at the six reach locations sampled are presented in Figure 4 and Figure 5, respectively. The quality of the substrate for spawning is related to the overall size of the sediment. Substrate quality for spawning is a function of the proportion of suitable-sized gravel compared to that of large armor particles and the presence of smaller material in the substrate.The fish are capable of removing the fines as long as the redds are not re-covered with fines during incubation. Substrate sample results illustrated in Figure 4 and Figure 5 show comparatively similar grain-size distributions among study sites. Particle diameters $\left(\mathrm{d}_{50}\right)$ for the armor layer and substrate samples, respectively, were as follows: Reach $6=62 \mathrm{~mm}$ and $39 \mathrm{~mm}$; Reach $5=112$ $\mathrm{mm}$ and $36 \mathrm{~mm}$; Reach $4=109 \mathrm{~mm}$ and $20 \mathrm{~mm}$; Reach $3=91 \mathrm{~mm}$ and $18 \mathrm{~mm}$; Reach $2=118 \mathrm{~mm}$ and $31 \mathrm{~mm}$; and Reach $1=65 \mathrm{~mm}$ and $12 \mathrm{~mm}$. This is consistent with other studies that found coho (Oncorhynchus kisutch) spawning in gravel/cobble substrates containing less than 5 percent sand (Platts and others, 1979; Reiser and Bjornn, 1979). Figure 6 shows the reach-averaged distribution of grain size for the 6 sites along the Klamath River below Iron Gate Dam. The reach-averaged $\mathrm{d}_{50}$ for the armor, substrate, and fines were $90 \mathrm{~mm}$ (cobble), $25 \mathrm{~mm}$ (gravel), and $0.35 \mathrm{~mm}$ (sand), respectively.

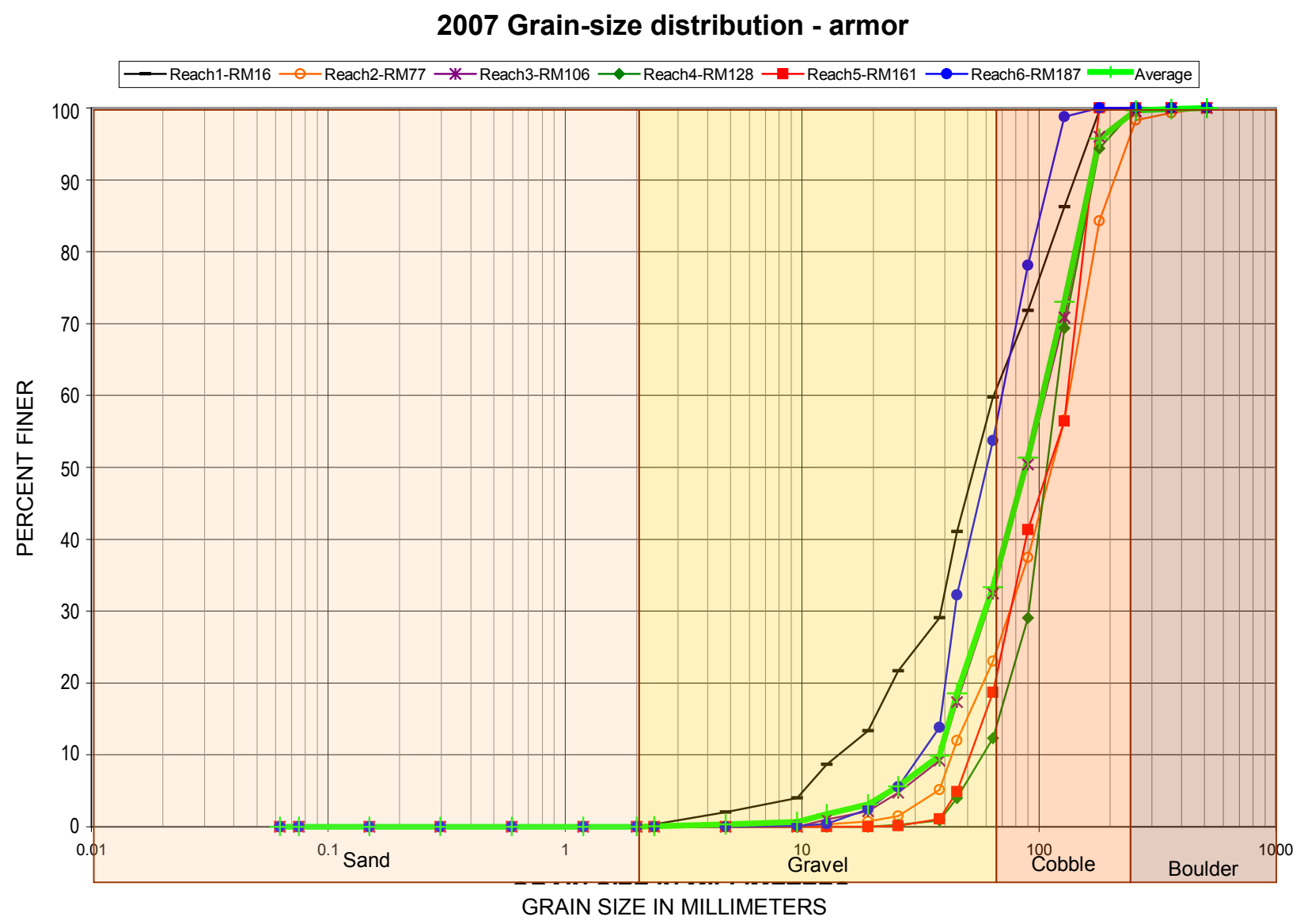

Figure 4. Distribution of armor grain size, by reach, for sediment samples taken in 2007. 


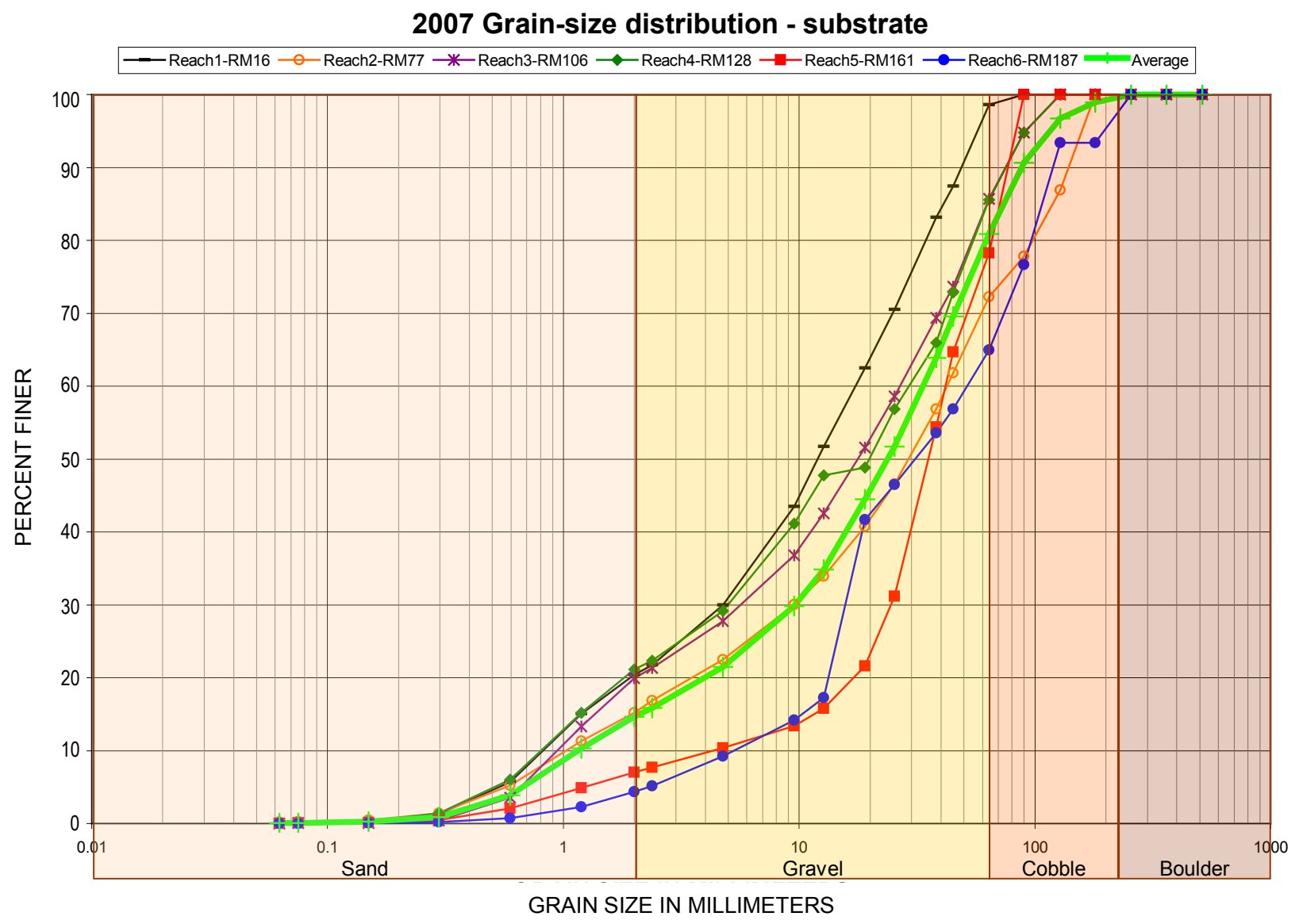

Figure 5. Distribution of substrate grain size, by reach, for sediment samples taken in 2007. 


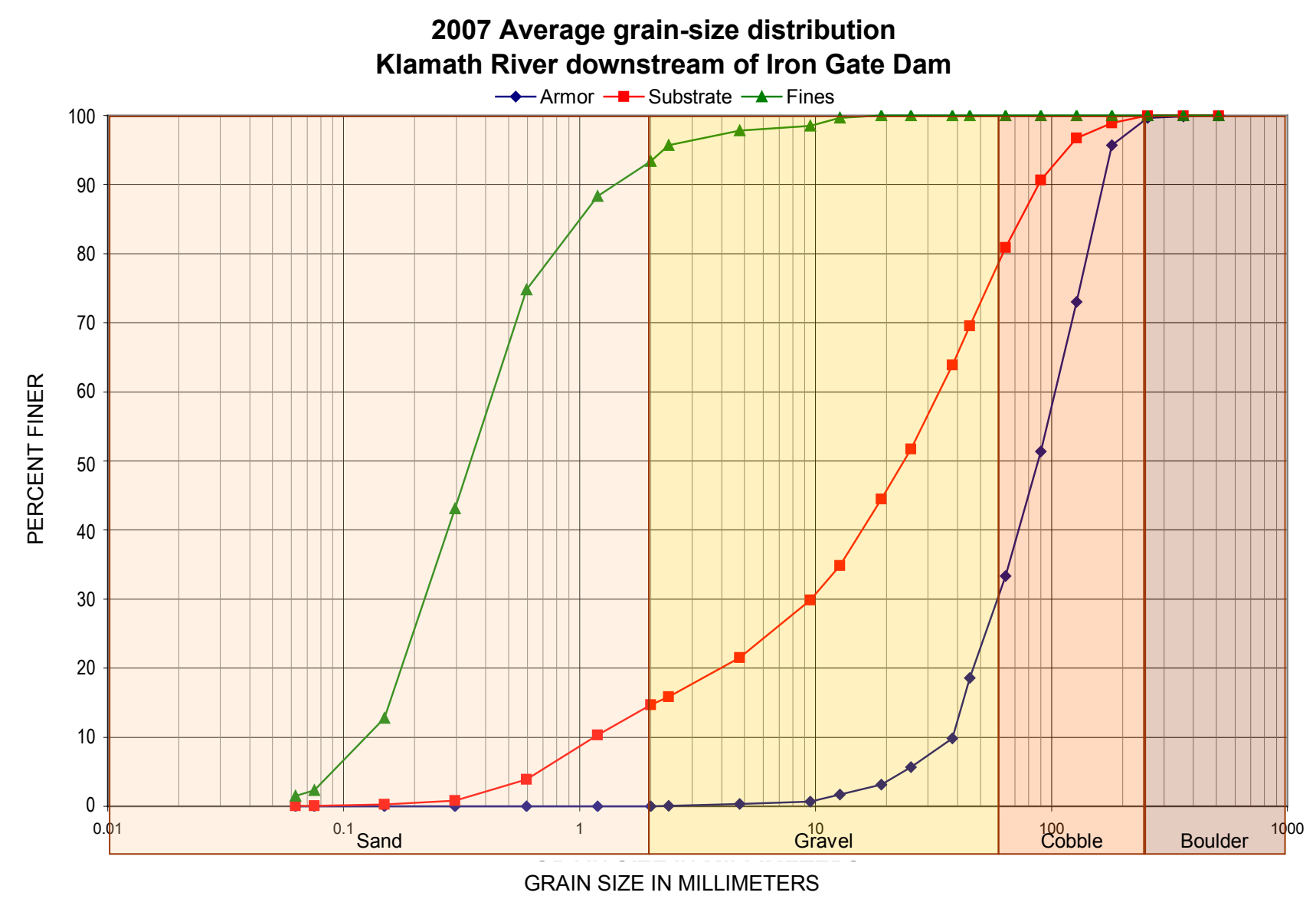

Figure 6. Distribution of average grain size for sediment samples taken in 2007 below Iron Gate Dam.

From the field samples collected during 2007, the infilling of coarse-grained bar sediments by fine-grained sediments do not appear to be excessive and most likely occur during dry years, summer months, or periods of low flow when transport of fine sediment is limited. Figure 5 shows that, in reaches 5 and 6 , the substrate contained less than 8 percent sand/fines and, in the lower four reaches, less than 20 percent sand/fines. The greatest amount of sand and fine sediment occurred in the lower 3 reaches and generally appeared to be associated with large bars, especially near tributary confluences. The average grain-size distribution presented in Figure 5 and Figure 6 show the relative availability of spawning material (gravel/cobble) below Iron Gate Dam. The gradations within each reach may vary from those sampled in 2007 if the discharges in the river vary significantly from the flow experienced in 2007. A long period of low flows (drought conditions) without any supplemental flushing flows could result in extended periods of low velocity and additional fine sediment deposition downstream from Iron Gate Dam. This could cause spawning gravels to become filled with fine sediment and provide habitat conditions conducive to the establishment of aquatic vegetation, two conditions that are favorable to the spread of C. shasta in the Klamath River Basin (Stocking and Bartholomew, 2006). 


\section{Flushing Flow Needs Below Iron Gate Dam}

There are four zones of sediment movement in gravel-bed rivers (Milhous, 2000, 2003), and they are presented in Table 3 along with the range of dimensionless shear stress values and corresponding discharges specific to the Klamath River below Iron Gate Dam (Figure 7).

Table 3. The dimensionless shear stress and discharges used to calculate the number of days the substrate is flushed of fines or moved and the number of days the substrate is stable.

\begin{tabular}{lccccc}
\hline \multirow{2}{*}{ Substrate state } & \multicolumn{2}{c}{ Dimensionless shear stress } & & \multicolumn{2}{c}{ Discharge (ft $3 / \mathbf{s})$} \\
\cline { 2 - 3 } \cline { 5 - 6 } & Lower limit & Upper limit & & Lower limit & Upper limit \\
\hline Immobile & 0.000 & 0.009 & & 0.0 & 2,500 \\
Stable & 0.009 & 0.021 & & 2,500 & 5,000 \\
Flushing of Fines & 0.021 & 0.035 & & 5,000 & 8,700 \\
Movement & 0.045 & ----- & & 11,250 & ----- \\
(armor disturbance) & & & &
\end{tabular}

[ $\mathrm{ft}^{3} / \mathrm{s}$, cubic feet per second; ----, no limit applied]

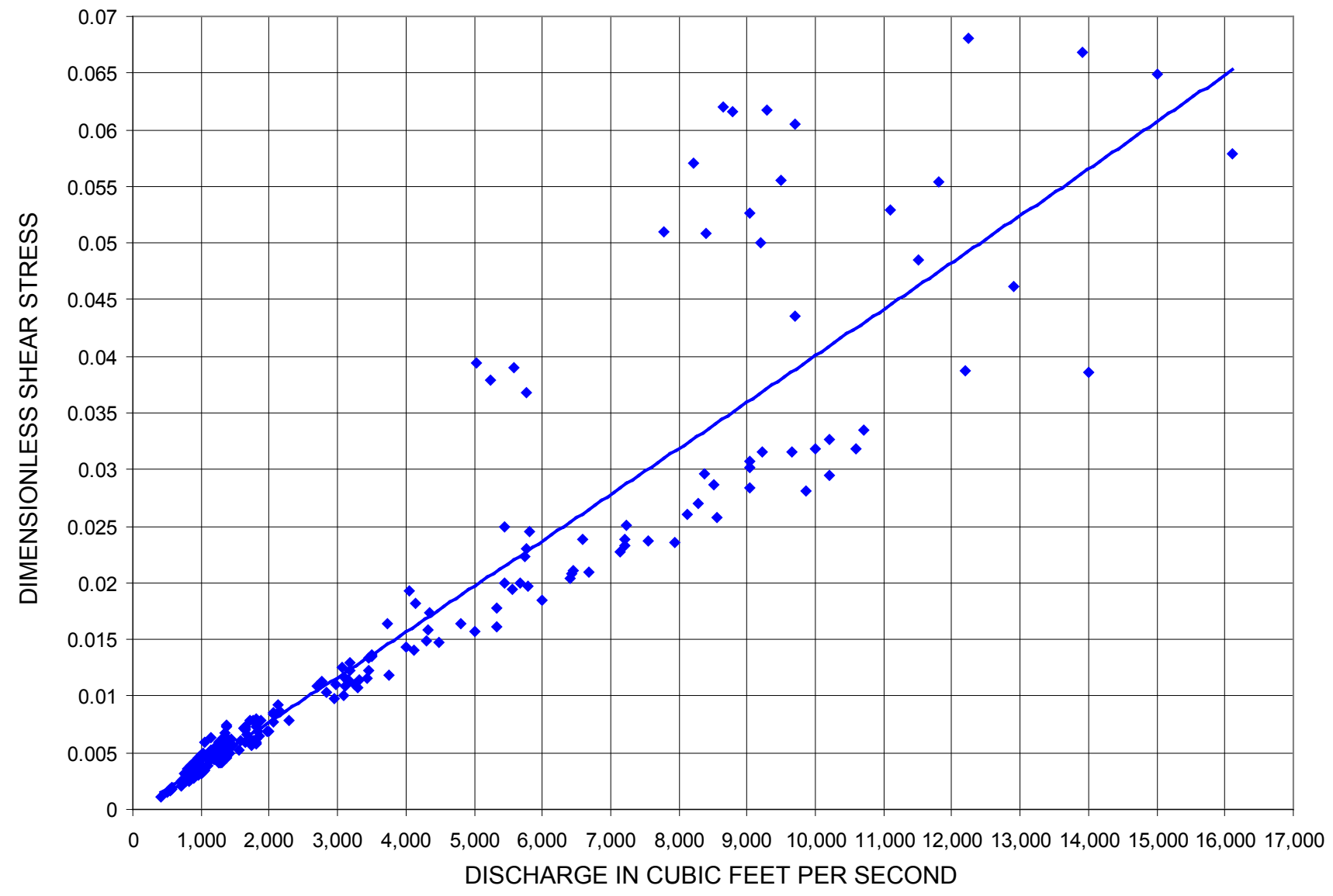

Figure 7. The dimensionless shear stress of the Klamath River below Iron Gate Dam calculated using the discharge measurement summary data (equation 1 ). 
As discussed previously, reaches 4 and 5 appear to be the most critical reaches for the salmon fisheries; therefore, based on figure 7, the lower limit on movement was determined to be approximately $11,250 \mathrm{ft}^{3} / \mathrm{s}$ based on a dimensionless shear stress of 0.045 . This value was used as the critical discharge in the channel maintenance capacity index calculation (see Appendix 1). Figure 8 shows a comparison of the critical shear stress ratio and discharge for each of the six reaches, and Figure 9 shows a comparison of the the average critical shear stress ratio and discharge for reaches 4,5 , and 6 for the armor and substrate material.

Estimates of the streamflows needed to maintain the substrate of the Klamath River below Iron Gate Dam have been made by Ayers and Associates (1999) and by the present study. These estimates (in $\mathrm{ft}^{3} / \mathrm{s}$ ) are given in Table 4.The estimated streamflow needs are not the same because different data and logic were used to interpret the data. For this study, flushing flows were analyzed by using a reachaveraged approach and did not distinguish between pool and riffle features within each reach. In contrast, Ayres and Associates analysis distinguished between sediment contained in pools and riffle sections within each reach and determined flows required to move the sediment within the pool and riffle sections independently. Neither study has estimated the flows needed to remove the filamentous algae attached to the substrate. When the streamflows exceed $15,000 \mathrm{ft}^{3} / \mathrm{s}$, a loss of spawning gravels is expected, with the quantity removed dependent on how long the streamflows exceed $15,000 \mathrm{ft}^{3} / \mathrm{s}$.

Historically, the river has had the capacity to move sediment just below Iron Gate Reservoir, but there have been periods when the capacity was very low. The change in sediment transport capacity is presented in Figure 10 for the Klamath River below Iron Gate Dam. The most interesting observation from Figure 10 is the low sediment transport index (2.8) averaged during the period 1924-1961 compared to 8.5 averaged during the period1962-2008. The frequency of the ability of the Klamath River to maintain the channel after about 1956 is not the same as it was for the 32 years before 1956. The channel maintenance capacity index (Milhous, 1995) shows the annual variation of the stream's ability to clean the channel and move sediment (Figure 11). The results indicate that if the future is more like the pre-1961period (low transport capacity) than the more recent period, there will be significant sediment issues in the Klamath River below Iron Gate Dam. It seems that during normal or wet years, winter months, and periods of high flow, sediments are flushed either downstream or deposited on higher surfaces. The recent drought conditions during 2000-2005 probably resulted in extensive finegrained sedimentation along the river, which in turn may have caused increased establishment of aquatic vegetation and increased concentrations of $C$. shasta.

Figure 12 illustrates the number of days in a year during which the streambed substrates are in their various states of movement (as listed in Table 4). It indicates that there are periods when even small amounts of sediment stored during a given year can provide the fines and sand that yield a substrate favorable for the establishment of aquatic vegetation (for example, the 2000-2005 period). To limit the amount of fines that are deposited during extended periods of low flow, supplemental flows would be required to keep the fines flushed through the system and minimize the establishment of the aquatic vegetation. During water years 2000 and 2001, it appears that flows in the river just downstream of Iron Gate Dam were not high enough to flush the fines, and there were only one or two flows high enough to possibly clean the gravels. Figure 13 shows that from 2000-2005, flows required to clean the gravels and move the armor layer (rework the channel) did not exist and flushing flows were very limited during the 5-year period. 


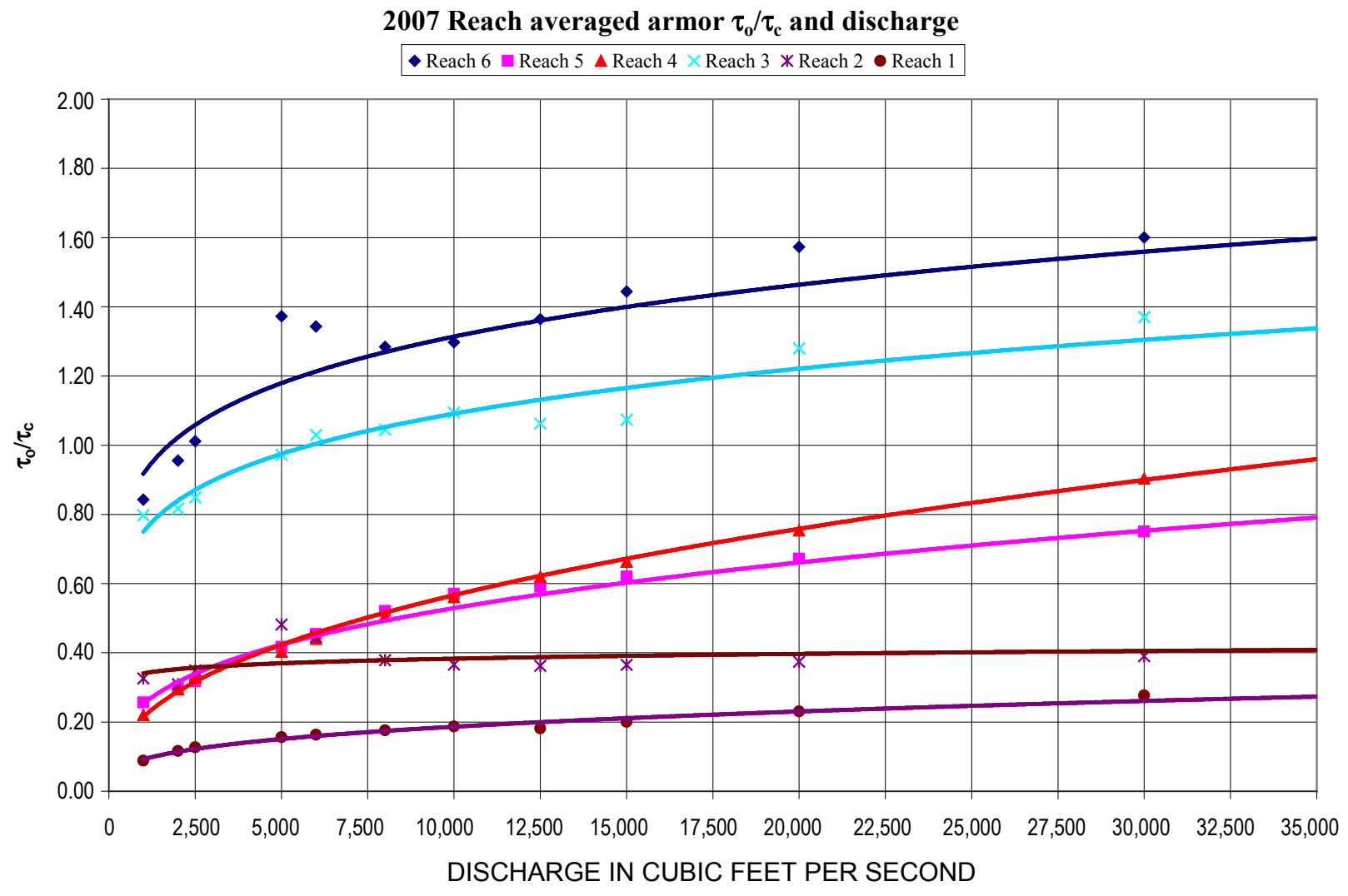

Figure 8. The armor shear stress ratio (bed shear/crital shear) of the Klamath River below Iron Gate Dam calculated using the six reach locations and corresponding reach hydraulics from the one-dimensional hydraulic model HEC-RAS. 
(a)

2007 Reach 4, 5, and 6 averaged armor $\tau_{0} / \tau_{\mathrm{c}}$ and discharge

Klamath River below Iron Gate Dam (RM187-RM128)

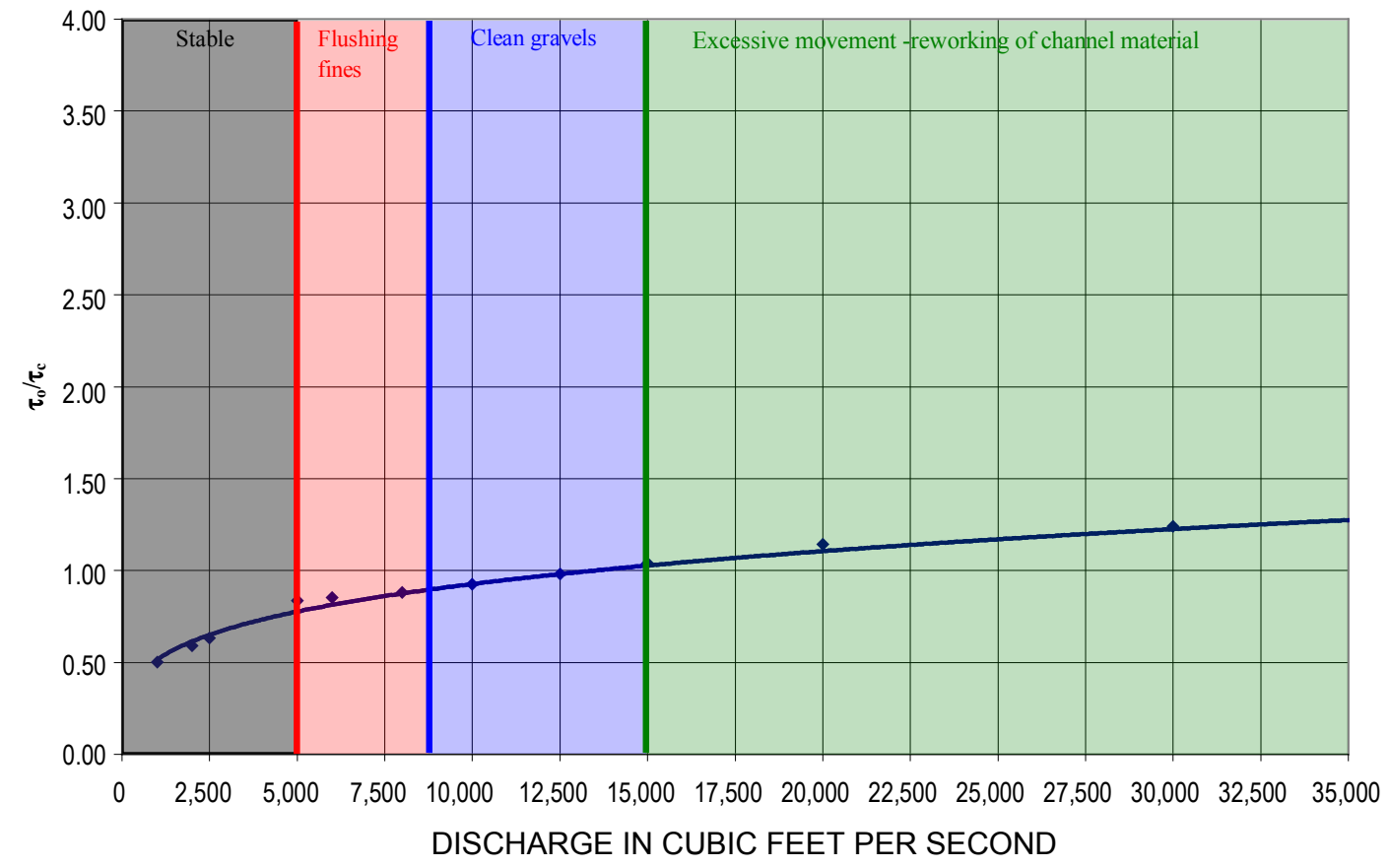

(b)

2007 Reach 4, 5, and 6 averaged substrate $\tau_{\mathrm{o}} / \tau_{\mathrm{c}}$ and discharge

Klamath River below Iron Gate Dam (RM187-RM128)

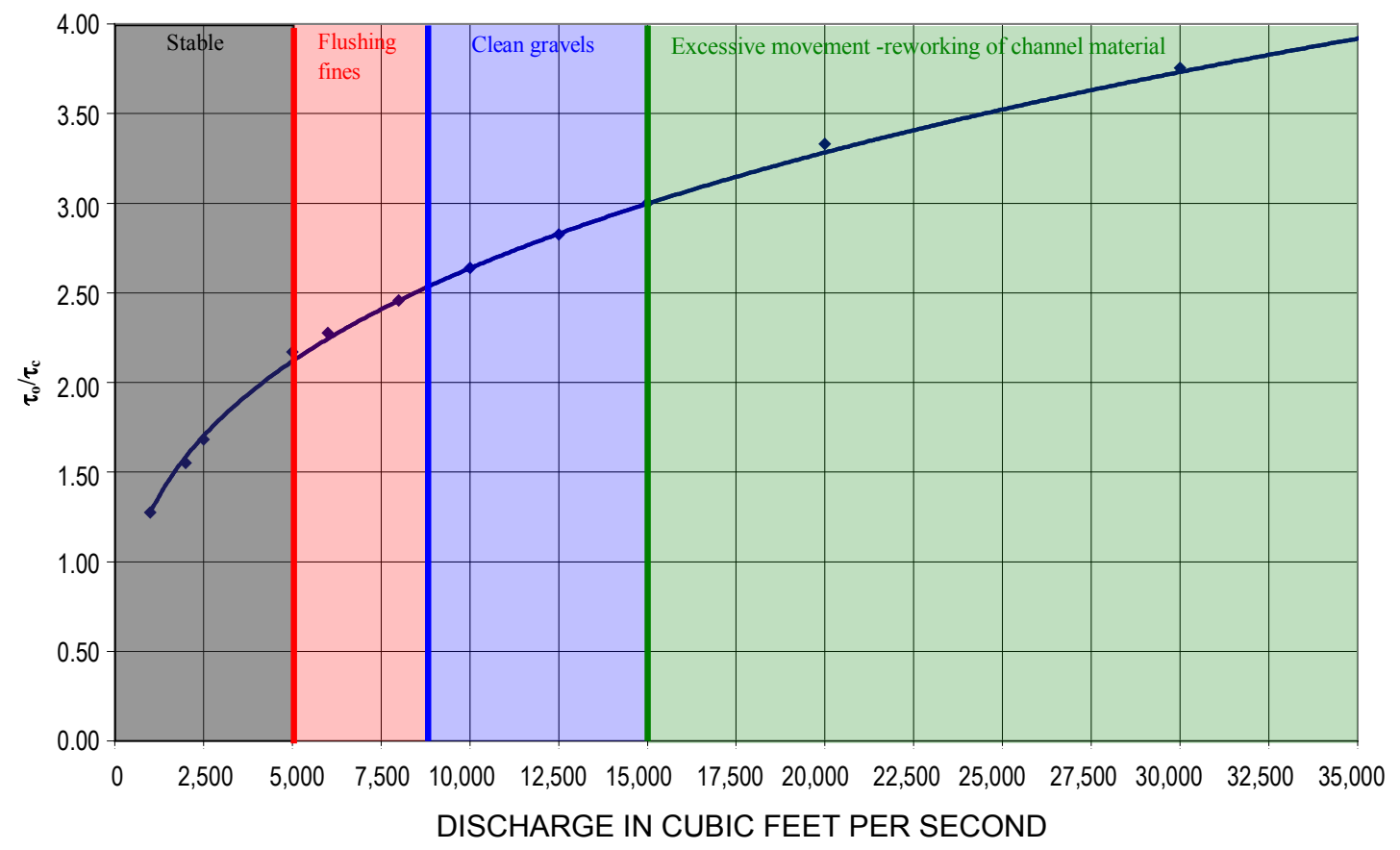

Figure 9. The average armor (a) and substrate (b) shear stress ratio (bed shear/crital shear) of the Klamath River below Iron Gate Dam calculated using the three upper-most reach locations and corresponding hydraulic results from the one-dimensional hydraulic model HEC-RAS. 
Table 4. Comparison of Ayres and Associates and U.S. Geological Survey estimated streamflows needed to flush fine sediment in the Klamath River below Iron Gate Dam.

\begin{tabular}{lcc}
\hline \multicolumn{1}{c}{ Action } & USGS & $\begin{array}{c}\text { Ayres and } \\
\text { Associates }\end{array}$ \\
\hline Stable bed & $<2,500$ & \\
Flush fines & 2,500 to 8,700 & 2,500 \\
Clean pools & & 5,400 \\
Clean gravels & 11,250 & 9,800 \\
Remove armor & $>15,000$ & \\
\hline
\end{tabular}

\section{Annual sediment transport capacity index} Klamath River at Iron Gate Dam

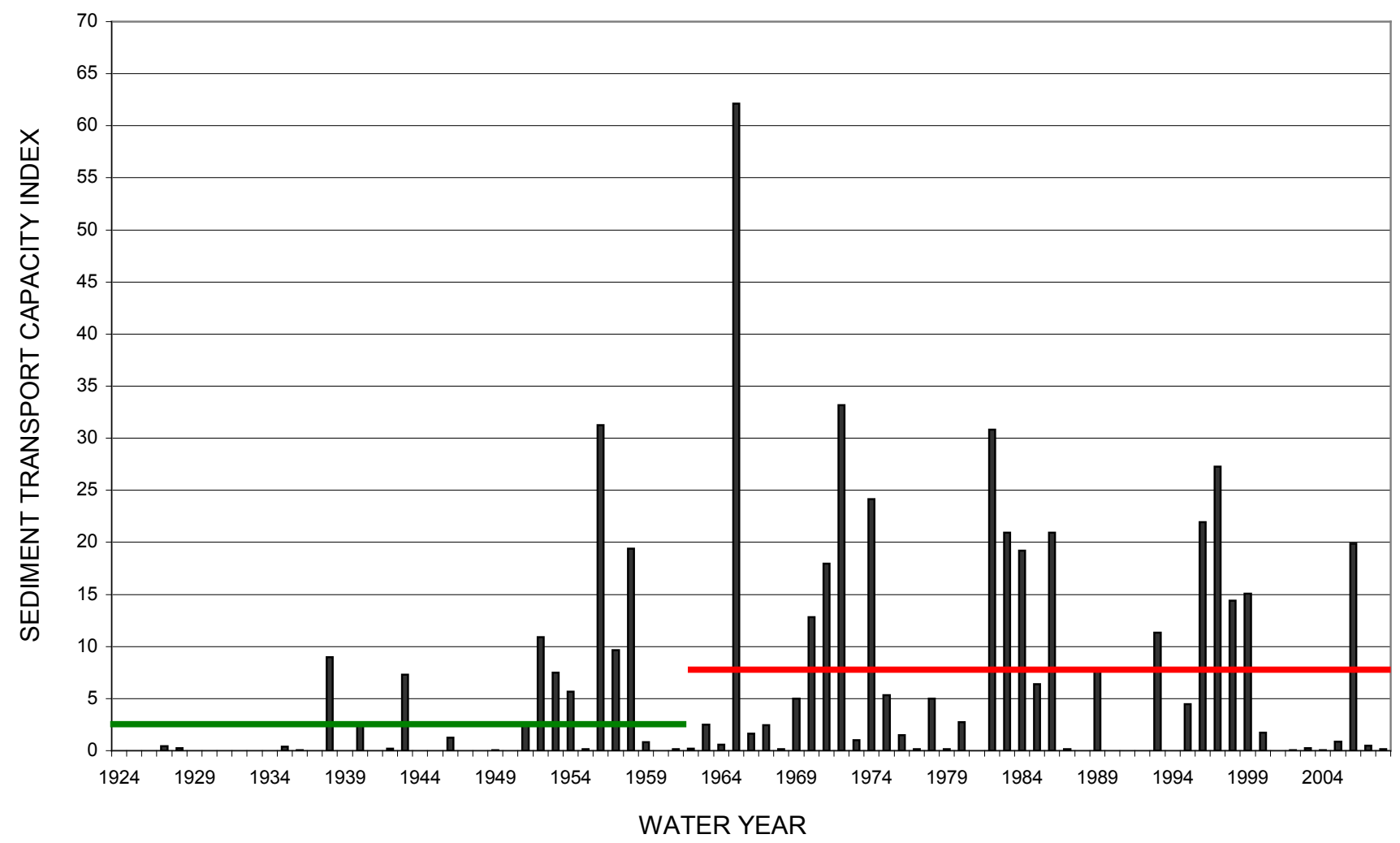

Figure 10. Annual sediment transport capacity index (ASTCI) for the Klamath River below Iron Gate Dam, California. Green line represent the average ASTCI prior to Iron Gate Dam and the red line represents the average ASTCl post Iron Gate Dam. The equation for the index is stci $=\left(\left((\mathrm{QD}-2500 \mathrm{ft} / \mathrm{s})^{\wedge} 1.4\right)^{\star} \mathrm{QD}\right) /(10000$ $\left.\mathrm{ft}^{3} / \mathrm{s}^{\wedge} 2.4\right)$ 
Annual channel maintenance capacity index

Klamath River at Iron Gate Dam

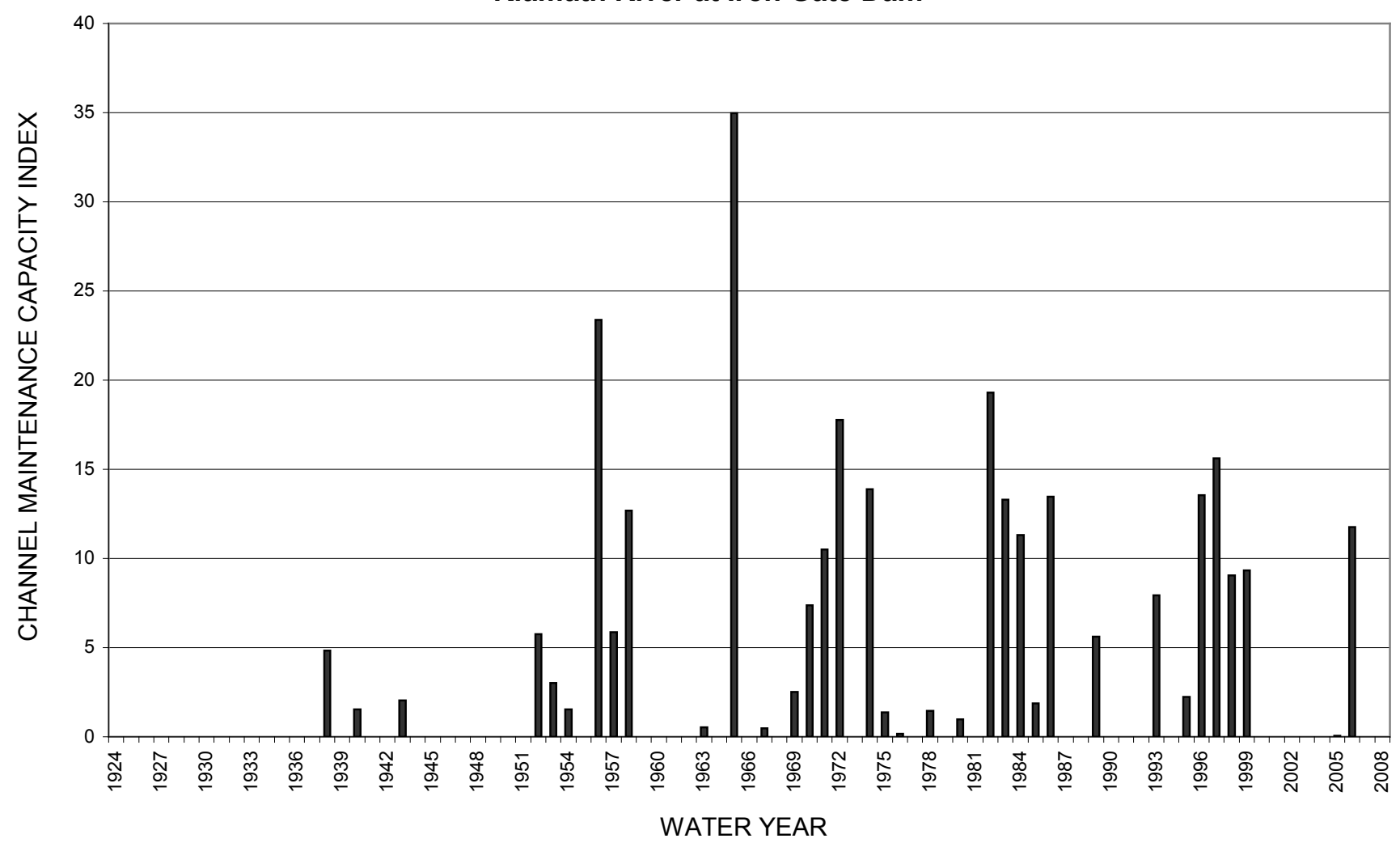

Figure 11. Annual channel maintenance capacity index (ACMCI) for the Klamath River below Iron Gate Dam, California. The equation for the index is $\mathrm{cmci}=\left(\mathrm{QD}^{\wedge} 0.87-5000 \mathrm{ft}^{3} / \mathrm{s}^{\wedge} 0.870 /\left(10000 \mathrm{ft}^{3} / \mathrm{s}^{\wedge} 0.87\right)\right.$. Data for 1924 -1960 were for the streamgage below Copco Dam a short distance upstream from the present streamgage and at a location within the Iron Gate reservoir. 


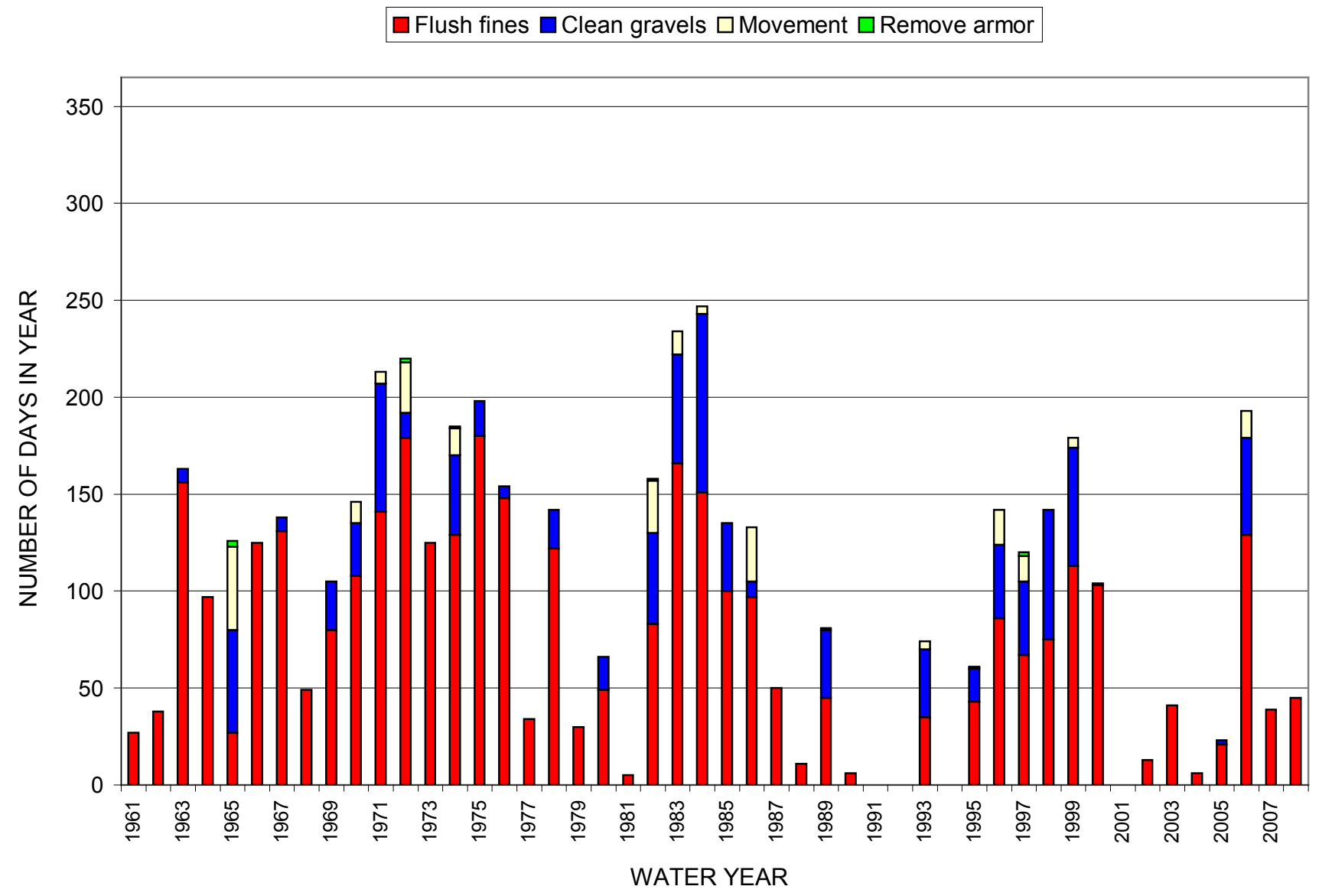

Figure 12. Number of days each water year during which streamflows were adequate to keep sediment out of the substrate or remove fines from the substrate. The number of days between the top of a given bar and the line are days during which any sediment in the river was likely to be absorbed by the substrate. 
Reach 4,5,6 (RM128,161,187) average flushing flow anaysis

Reach 4-Seaid streamgage Reach 5 and 6-Iron Gate and Shasta streamgages

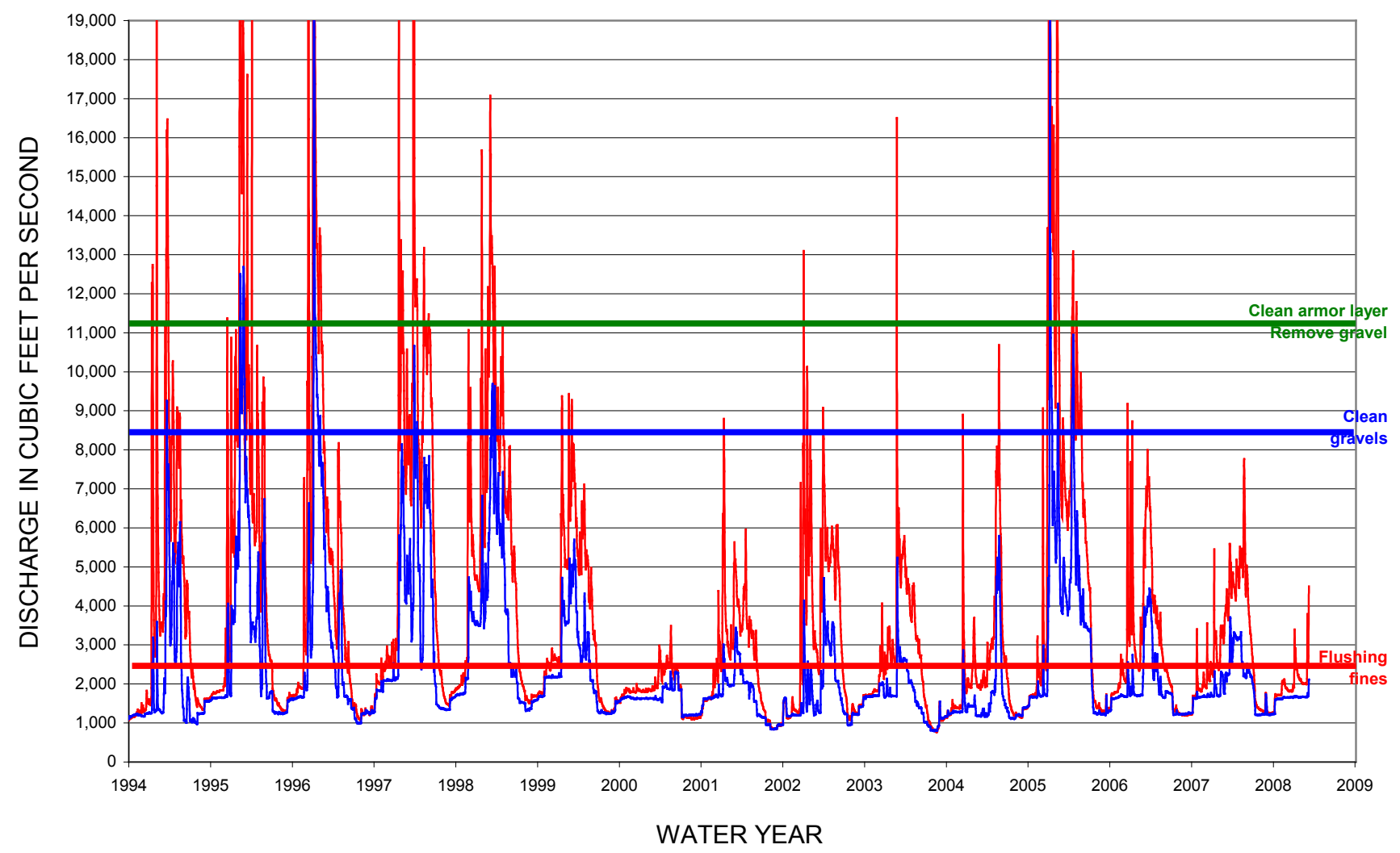

Figure 13. Streamflow requirements to keep sediment out of the substrate or remove fines from the substrate for reaches 4,5 , and 6 on the Klamath River below Iron Gate Dam.

\section{Conclusions}

- Field samples collected during 2007 indicate that infilling of coarse-grained bar sediments by finegrained sediments are not excessive and most likely occur during dry years, summer months, or periods of low flow when transport of fine sediment is limited. The drought conditions that existed from 1986 to 1994 and from 2000 to 2005 probably resulted in extensive fine-grained sedimentation along the river. From the flushing flow analysis, it appears that during normal or wet years, winter months, and periods of high flow, sediments are flushed either downstream or deposited on higher surfaces.

- The most significant deposits of fine sediments occur in the lower 70 miles of the river and are generally associated with large bars in the reach. Hardy and Addley (2001) note that this area has not been used historically for spawning to any significant degree since the primary spawning areas are associated with the upstream end of the reach near Iron Gate Dam (reaches 4, 5, and 6) and the various tributaries.

- In terms of aquatic vegetation, fine-grained sediments that are not flushed through the system provide a substrate for establishment. If flows remain relatively low for an extended period of time, 
repeated annual establishment of the aquatic vegetation will occur. Therefore, it is apparent that the spread of this vegetation and its effects are highly dependent on the duration and intensity of low flow and drought conditions.

- It appears that releases from Iron Gate Dam as far downstream as Seiad Valley are important in maintaining flow conditions to flush the fines and clean the gravels in the river during summer months, or during drought years. Sediment transport studies indicate that supplemental flows during dry or drought conditions may provide some flushing flows in reaches downstream of the dam. Under normal conditions, flushing of the fines and cleaning of the gravels occurs regularly, but could be supplemented or enhanced during drier summer months.

- For purposes of flushing fine sediments during drought years or dry summer months, flows in the range of 2,500-5,000 $\mathrm{ft}^{3} / \mathrm{s}$ during a period of days may be necessary. Providing these types of flows in a manner similar to a storm pulse would provide the best opportunity to flush the fines and clean some of the gravels given the upper ranges of flows are achieved. 


\section{References Cited}

Anglin, D.R., 1994, Lower Klamath River instream flow study: Scoping evaluation for the Yurok Indian Reservation: Vancouver, Wash., Department of Interior, U.S. Fish and Wildlife Service, Interagency Agreement No. AG1J5200003, 46 p.

Ayres and Associates, 1999, Geomorphic and sediment evaluation of the Klamath River, California, below Iron Gate Dam: Fort Collins, Colo., 362 p.

Einstein, H. A., and Barbarossa, N. L., 1952, River channel roughness: Journal of Hydraulic Engineering, $117 \mathrm{p}$.

Hardy, T., and Addley, R.C., 2001, Evaluation of interim instream flow needs in the Klamath River, phase II-final report to the U.S. Fish and Wildlife Service: Utah State University Institute for Natural Systems Engineering, Utah Water Research Laboratory, Utah State University, Logan, Utah.

National Biological Service, 1995, Compilation of Phase I reports for the Klamath River Basin-report to the Technical Rok Group of the Klamath River Basin Fisheries Task Force: River systems management section NBS-midsontinent ecological science center, Fort Collins, Colo.

U.S. Army Corps of Engineers, 2006, HEC RAS River Analysis System, users manual, version 4.0Report CPD-68: Davis, Calif., Institute for Water Resources, Hydrologic Engineering Center.

Kellerhals, R., and Bray, D.I., 1971, Sampling procedures for coarse fluvial sediments: Journal of the Hydraulics Division, Proceedings of the American Society of Civil Engineers, v. 97, no. HY8 August 1971, p. 1,165-1,180.

Klamath River Basin Fisheries Task Force, 1991, Long-range plan for the Klamath River Basin Conservation Area fishery restoration program: U.S. Fish and Wildlife Service, Yreka, Calif.

Knighton, D., 1998, Fluvial forms and processes a new perspective: New York, New York, John Wiley \& Sons Inc., p383.

Leopold, L.B., Wolman, M.G.,and Miller, J.P., 1964, Fluvial processes in geomorphology: San Fransisco, Calif., W. H. Freeman and Company, p. 552.

Milhous, R.T., 1995, Suspended and bed load in flushing flow analysis: Trinity River case study, in Morel-Seytoux, H.J., ed., Proceedings of the fifteenth annual American Geophysical Union Hydrology Days: Atherton, Calif., Hydrology Days Publications, p. 173-184.

Milhous, R.T., 2000, Numerical modeling of flushing flows in gravel-bed rivers, in Klingeman, P.C., Beschta, R.L., Komar, P.D., and Bradley, J.B., eds., Gravel-bed rivers in the environment: Littleton, Colo., Water Resources Publications, p. 579-608.

Milhous, R.T., 2003, Reconnaissance-level application of physical habitat simulation in the evaluation of physical habitat limits in the Animas Basin, Colorado: U.S. Geological Survey Open-File Report $03-222,16 \mathrm{p}$.

PacifiCorp, 2004, Klamath hydroelectric project study plans, Analysis of project effects on sediment transport and river geomorphology: Portland, Oregon, PacifiCorp.

Stocking, R.W., Holt, R.A., Foott, J.S., and Bartholomew, J.L., 2006, Spatial and temporal occurrence of the salmonid parasite Ceratomyxa shasta (Myxozoa) in the Oregon-California Klamath River Basin: Journal of Aquatic Animal Health, v. 18, p. 194-202.

Sutton, R. and Milhous, R.T., 2008, Klamath River salmon redd scour study, 2007-2008: Denver, Colo., U.S. Bureau of Reclamation, Technical Memorandum No. 86-68290-08-02.

Wolman, M.G., 1954, A method of sampling coarse bed material: American Geophysical Union, Transactions, v. 35, p. 951-956. 


\section{Appendix 1}

\section{The Sediment Transport Capacity Index}

This appendix presents the logic used in computing the sediment transport capacity index. The concentration of sediment in a river is empirically related to the discharge, expressed as

$$
C=a\left(Q-Q_{\text {critical }}\right)^{b}
$$

where

$C=$ concentration of sediment in milligrams per liter, $Q=$ discharge in cubic feet per second,

$Q_{\text {critical }}=$ critical discharge in cubic feet per second for a given grain size, and $a$ and $b=$ empirical coefficients.

An example of an empirical relation for a streamgage in the Klamath River Basin is given on figure 14. The empirical relation shown on figure 14 was obtained using least absolute deviation regression. The equation is shown below.

$$
C=0.002(Q)^{1.4}
$$

The critical discharge was considered to be zero for the suspended sediment at this location. The units of the discharge are cubic feet per second $\left(\mathrm{ft}^{3} / \mathrm{s}\right)$ and concentrations are $\mathrm{mg} / \mathrm{L}$.

The total suspended load is calculated using the equation

where

$$
Q_{s l}=c\left(Q-Q_{\text {critical }}\right)^{d}
$$

$Q_{\mathrm{sl}}=$ total suspended load in tons per day,

$Q=$ discharge in cubic feet per second,

$Q_{\text {critical }}=$ critical discharge in cubic feet per second for a given grain size, and $c$ and $d=$ empirical coefficients.

For the Klamath River near Orleans, the toal suspended load equation is presented in figure 15.

In the Klamath River Basin, the critical discharge has been found to be zero for the totalsuspended load but other than zero for the sand load. 


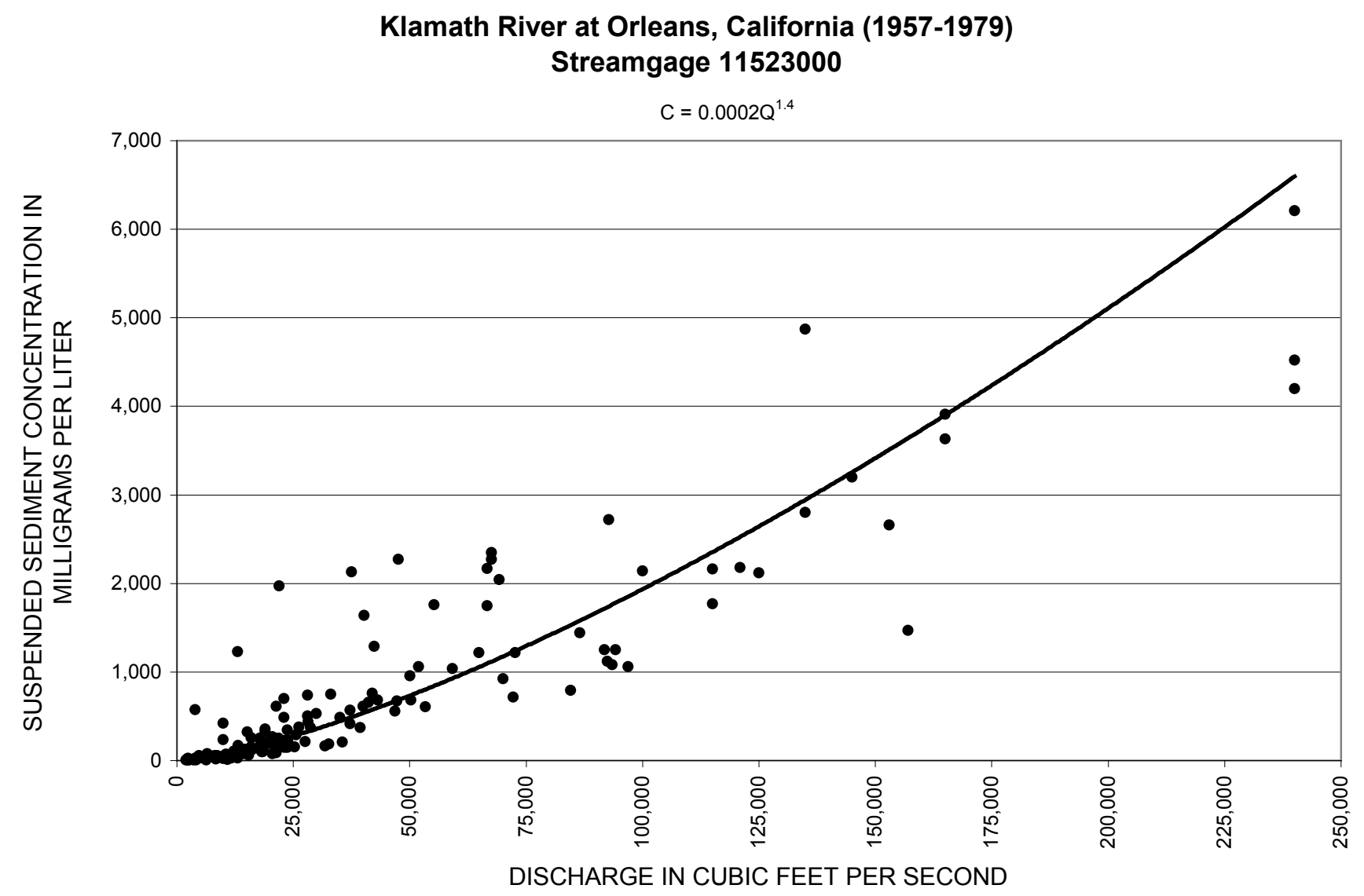

Figure 14. Measured concentrations of suspended sediment in the Klamath River near Orleans, California, as related to the discharge in the river. 


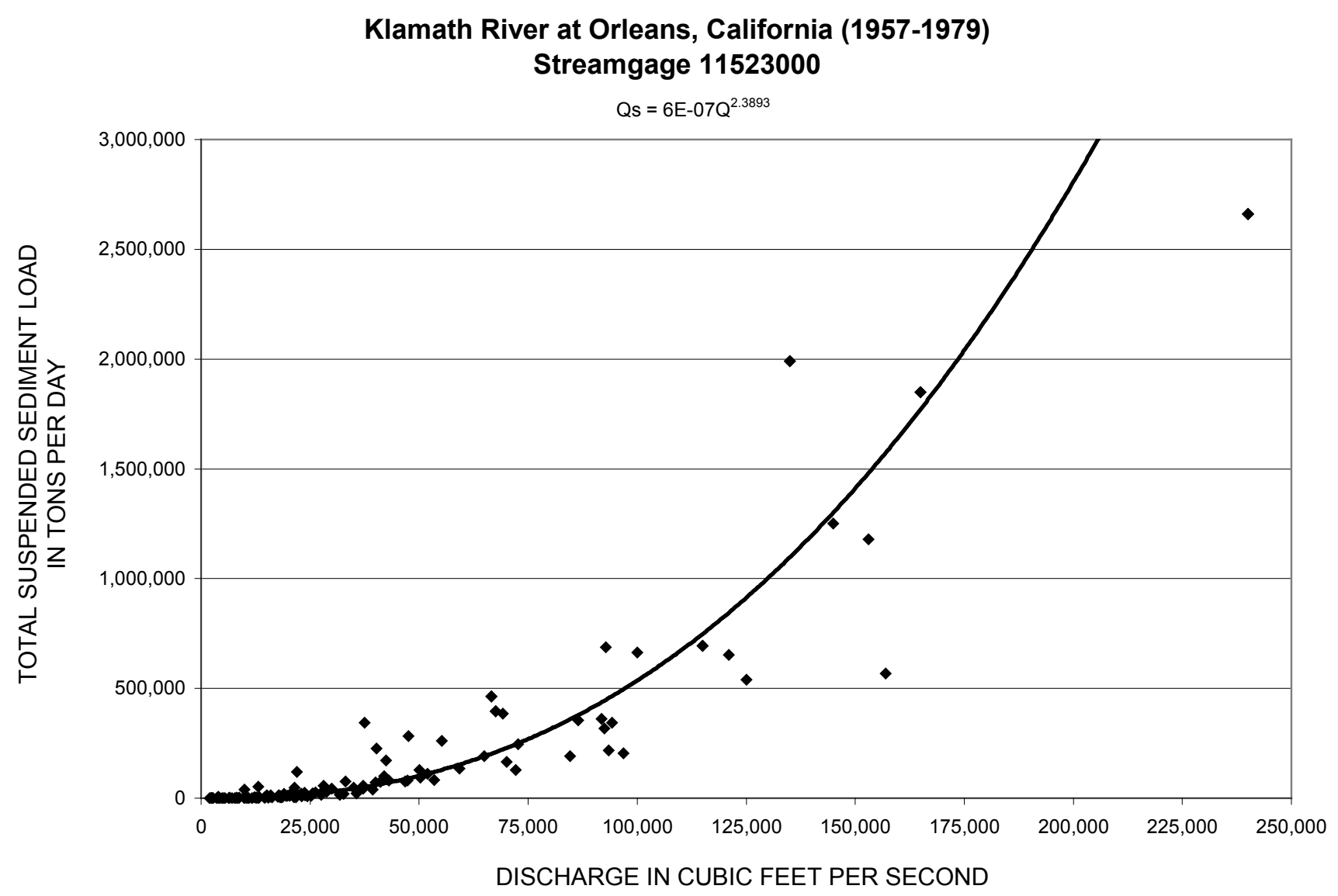

Figure 15. Measured total sediment load in the Klamath River near Orleans, California, as related to the discharge in the river.

An index of the river's ability to transport sediment, refered to as the sediment transport capacity index (stci), is formed by dividing the sediment load at a given discharge by the sediment load at a reference discharge. The equation is then

where

$$
\text { stci }=\frac{Q_{s l} \text { at } Q}{Q_{s l} \text { at } Q_{\text {ref }}}=\frac{c\left(Q-Q_{\text {critical }}\right)^{d} Q}{c\left(Q_{\text {ref }}-Q_{\text {critical }}\right)^{d} Q_{r e f}}
$$

$Q_{\mathrm{sl}}=$ total suspended load in tons per day,

$Q=$ discharge if interest in cubic feet per second, and

$Q_{\text {ref }}=$ reference discharge in cubic feet per second used to make the index dimensionless.

Experience with using the index has shown that there is no loss in the application of the equation shown above if it is multiplied by a constant equal to $\left(\left(\mathrm{Q}_{\mathrm{ref}}-\mathrm{Q}_{\mathrm{crt}}\right) / \mathrm{Q}_{\mathrm{ref}}\right)^{\mathrm{d}}$. The equation then becomes 


$$
s t c i=\frac{\left(Q-Q_{\text {criical }}\right)^{d} Q}{Q_{\text {ref }}^{d+1}}
$$

In most applications in this paper the stci is calculate using daily discharges. The annual sediment transport capacity index (ASTCI) is the sum of daily values during a year.

The power coefficient from the regression between suspended concentraton and discharge was used as the $b$ term (1.4) in the sediment transport capacity equation to calculate values of the sediment transport capacity for each day and to sum the daily values over some period of time. In most situations, the period of time is a water year (October 1-September 30 in North America).

$$
\text { ASTCI }=\sum \text { stci }=\sum\left((\mathrm{Q}-\mathrm{Q} c r t){ }^{\mathrm{d}} \mathrm{Q}\right) / \mathrm{Qref}^{\mathrm{d}+1}
$$
figure 16 .

The annual value of the stci for the Klamath River at Orleans, California, is presented in

\section{Annual sediment transport capacity index \\ Klamath River at Orleans, California}

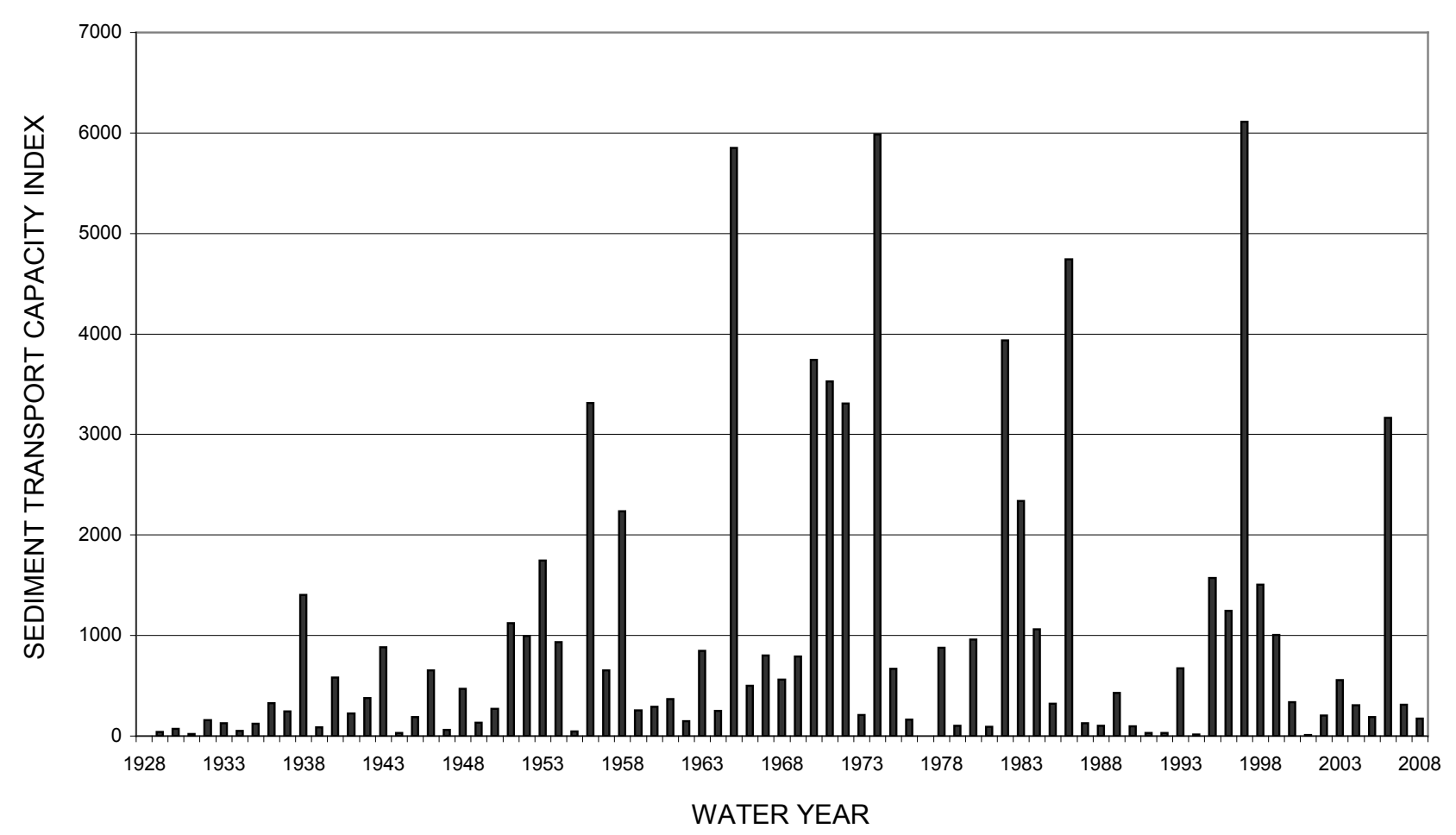

Figure 16. Annual sediment transport index for the Klamath River at Orleans, California. The reference discharge used was 10,000 cubic feet per second, the critical discharge used was 2,500 cubic feet per second, and the power term was 1.4 . 


\section{Channel Maintenance Capacity Index}

The starting premise when developing an index of a river's ability to maintain its channel (cmci) is that the total shear stress on the streambed can be divided into two components that sum to the total shear stress:

$$
\tau(\text { total })=\tau(\text { grain })+\tau(\text { bar })
$$

where

$\tau$ (grain) is the shear stress applied to the sediment in the channel, and $\tau$ (bar) is the shear stress applied to the channel form.

The concept of dividing the shear stress was taken from Einstein and Barbarossa (1952).

The next consideration is that the discharge important to the channel maintenance process is the channel-forming discharge, which is the bankfull discharge with an approximate return period of one in two years.

The shear stress applied to the streambed is

$$
\Omega=\tau * \mathrm{~W}
$$

where

$\Omega$ is the force on a unit length of stream,

$\tau$ is the shear stress on a unit area, and

$\mathrm{W}$ is the width of the stream.

The channel-forming discharge occurs when the discharge exceeds the median annual peak discharge and is the bed force maintaining the channel. The channel-maintenance force is then

$$
\Omega(\text { channel maintenance })=\Omega(\text { total })-\Omega(\text { median } Q)
$$

The strear stress is calculated using the equation

$$
\tau=\gamma \mathrm{RS}
$$

where

$\mathrm{R}$ is the hydraulic radius,

$\mathrm{S}$ is the energy slope, and

$\gamma$ is the unit weight of water.

Using Mannings' equation this becomes

$$
\tau=\frac{\gamma v^{2} n^{2}}{R^{\frac{1}{3}}}
$$


The channel maintenance capacity index for a discharge greater than the median discharge is

$$
c m c i=\frac{\frac{\gamma v^{2} n^{2} W}{R^{\frac{1}{3}}}-\left(\frac{\gamma v^{2} n^{2} W}{R^{\frac{1}{3}}}\right)_{\text {critical }}}{\left(\frac{\gamma v^{2} n^{2} W}{R^{\frac{1}{3}}}\right)_{\text {reference }}}
$$

For a constant roughness and unit weight of water, the equation is

$$
c m c i=\frac{\frac{v^{2} W}{R^{\frac{1}{3}}}-\left(\frac{v^{2} W}{R^{\frac{1}{3}}}\right)_{\text {critical }}}{\left(\frac{v^{2} W}{R^{\frac{1}{3}}}\right)_{\text {reference }}}
$$

Using the hydraulic geometry relationship for calculating channel velocity, width, and depth as a function of discharge can be used to simplify the cmci equation given the theoretical value $b$ is $0.5, \mathrm{~m}$ is 0.23 and $\mathrm{f}$ is 0.27 from table 7-8 of Leopold, Wolman, and Miller (1964).

$$
\begin{aligned}
& \mathrm{V} \propto \mathrm{Q}^{\mathrm{m}} \\
& \mathrm{W} \propto \mathrm{Q}^{\mathrm{b}} \\
& \mathrm{d} \propto \mathrm{Q}^{\mathrm{f}}
\end{aligned}
$$

Taking depth and hydraulic radius as having the same power term (f) and substituting the hydraulic geometry equations, the equation for the cmci is

$$
\text { cmci }=\frac{Q^{0.87}-Q_{\text {critical }}^{0.87}}{Q_{\text {reference }}^{0.87}}
$$

where

$Q$ is the discharge,

$Q_{\text {critical }}$ is the critical discharge of interest (flushing flow, gravel movement, armor removal, etc.), and

$Q_{\text {reference }}$ is a reference discharge used to make the index dimensionless.

The annual value of the channel maintenance discharge (ACMCI) is the sum of the daily values of cmci, which is zero when the discharge is less than $Q_{\text {critical }}$.

The annual value of the channel maintenance capacity index for the Klamath River at Orleans, California, is presented in figure 17. 


\section{Annual channel maintenance capacity index}

Klamath River at Orleans, California

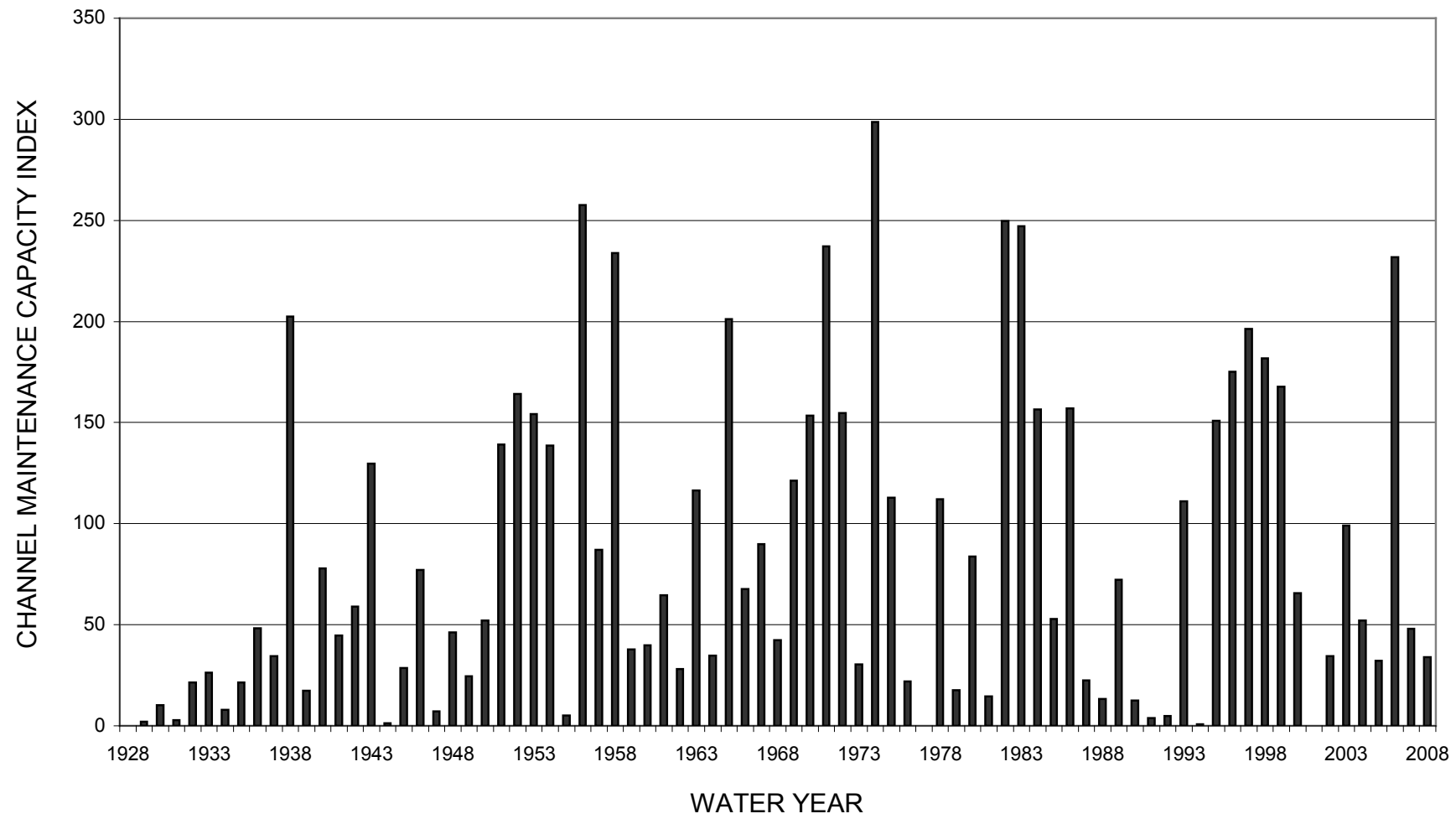

Figure 17. Annual channel maintenance capacity index for the Klamath River at Orleans, California. The reference discharge used was 10,000 cubic feet per second and the critical discharge was 8,700 cubic feet per second. 


\section{Appendix 2}

\section{Sediment Size Analysis Summary Data}

Table 5. Armor grain size analysis for sediment samples collected for six study sites below Iron Gate Dam.

\begin{tabular}{|c|c|c|c|c|c|c|c|}
\hline & \multirow{2}{*}{$\begin{array}{c}\text { Grain size } \\
(\mathrm{mm})\end{array}$} & \multicolumn{6}{|c|}{ Percent passing (armor) } \\
\hline & & Reach 1 & Reach 2 & Reach 3 & Reach 4 & Reach 5 & Reach 6 \\
\hline \multirow{2}{*}{ Boulder } & 512 & $100.00 \%$ & $100.00 \%$ & $100.00 \%$ & $100.00 \%$ & $100.00 \%$ & $100.00 \%$ \\
\hline & 362 & $100.00 \%$ & $99.33 \%$ & $100.00 \%$ & $100.00 \%$ & $100.00 \%$ & $100.00 \%$ \\
\hline \multirow{4}{*}{ Cobbles } & 256 & $100.00 \%$ & $98.33 \%$ & $99.50 \%$ & $100.00 \%$ & $100.00 \%$ & $100.00 \%$ \\
\hline & 180 & $99.66 \%$ & $84.29 \%$ & $96.00 \%$ & $94.41 \%$ & $100.00 \%$ & $100.00 \%$ \\
\hline & 128 & $86.23 \%$ & $56.55 \%$ & $70.88 \%$ & $69.37 \%$ & $56.42 \%$ & $98.79 \%$ \\
\hline & 90 & $71.81 \%$ & $37.46 \%$ & $50.43 \%$ & $29.04 \%$ & $41.33 \%$ & $78.14 \%$ \\
\hline \multirow{9}{*}{ Gravel } & 64 & $59.78 \%$ & $23.05 \%$ & $32.48 \%$ & $12.35 \%$ & $18.70 \%$ & $53.73 \%$ \\
\hline & 45 & $41.07 \%$ & $12.00 \%$ & $17.35 \%$ & $4.00 \%$ & $4.87 \%$ & $32.25 \%$ \\
\hline & 38.1 & $29.04 \%$ & $5.15 \%$ & $9.20 \%$ & $0.87 \%$ & $1.10 \%$ & $13.85 \%$ \\
\hline & 25.4 & $21.69 \%$ & $1.52 \%$ & $4.71 \%$ & $0.26 \%$ & $0.16 \%$ & $5.52 \%$ \\
\hline & 19 & $13.35 \%$ & $0.72 \%$ & $2.17 \%$ & $0.00 \%$ & $0.00 \%$ & $2.43 \%$ \\
\hline & 12.7 & $8.67 \%$ & $0.35 \%$ & $1.04 \%$ & $0.00 \%$ & $0.00 \%$ & $0.38 \%$ \\
\hline & 9.51 & $4.00 \%$ & $0.00 \%$ & $0.00 \%$ & $0.00 \%$ & $0.00 \%$ & $0.15 \%$ \\
\hline & 4.76 & $2.00 \%$ & $0.00 \%$ & $0.00 \%$ & $0.00 \%$ & $0.00 \%$ & $0.03 \%$ \\
\hline & 2.38 & $0.33 \%$ & $0.00 \%$ & $0.00 \%$ & $0.00 \%$ & $0.00 \%$ & $0.00 \%$ \\
\hline \multirow{7}{*}{ Sand } & 2 & $0.00 \%$ & $0.00 \%$ & $0.00 \%$ & $0.00 \%$ & $0.00 \%$ & $0.00 \%$ \\
\hline & 1.19 & $0.00 \%$ & $0.00 \%$ & $0.00 \%$ & $0.00 \%$ & $0.00 \%$ & $0.00 \%$ \\
\hline & 0.595 & $0.00 \%$ & $0.00 \%$ & $0.00 \%$ & $0.00 \%$ & $0.00 \%$ & $0.00 \%$ \\
\hline & 0.297 & $0.00 \%$ & $0.00 \%$ & $0.00 \%$ & $0.00 \%$ & $0.00 \%$ & $0.00 \%$ \\
\hline & 0.149 & $0.00 \%$ & $0.00 \%$ & $0.00 \%$ & $0.00 \%$ & $0.00 \%$ & $0.00 \%$ \\
\hline & 0.075 & $0.00 \%$ & $0.00 \%$ & $0.00 \%$ & $0.00 \%$ & $0.00 \%$ & $0.00 \%$ \\
\hline & 0.0625 & $0.00 \%$ & $0.00 \%$ & $0.00 \%$ & $0.00 \%$ & $0.00 \%$ & $0.00 \%$ \\
\hline
\end{tabular}

Table 6. Substrate grain size analysis for sediment samples collected for six study sites below Iron Gate Dam.

\begin{tabular}{rrrrrrrr}
\hline \multirow{5}{*}{ Boulder } & Grain size & \multicolumn{7}{c}{ Percent passing (substrate) } \\
\cline { 2 - 8 } & $(\mathrm{mm})$ & Reach 1 & Reach 2 & Reach 3 & Reach 4 & Reach 5 & Reach 6 \\
\hline \multirow{5}{*}{ Cobbles } & 512 & $100.00 \%$ & $100.00 \%$ & $100.00 \%$ & $100.00 \%$ & $100.00 \%$ & $100.00 \%$ \\
& 362 & $100.00 \%$ & $100.00 \%$ & $100.00 \%$ & $100.00 \%$ & $100.00 \%$ & $100.00 \%$ \\
& 256 & $100.00 \%$ & $100.00 \%$ & $100.00 \%$ & $100.00 \%$ & $100.00 \%$ & $100.00 \%$ \\
& 180 & $100.00 \%$ & $100.00 \%$ & $100.00 \%$ & $100.00 \%$ & $93.40 \%$ & $100.00 \%$ \\
& 128 & $86.86 \%$ & $100.00 \%$ & $100.00 \%$ & $100.00 \%$ & $93.40 \%$ & $86.86 \%$ \\
& 90 & $77.80 \%$ & $94.75 \%$ & $94.80 \%$ & $100.00 \%$ & $76.66 \%$ & $77.80 \%$ \\
Gravel & 64 & $72.26 \%$ & $85.71 \%$ & $85.58 \%$ & $78.28 \%$ & $64.94 \%$ & $72.26 \%$ \\
& 45 & $61.81 \%$ & $73.62 \%$ & $72.86 \%$ & $64.71 \%$ & $56.88 \%$ & $61.81 \%$ \\
& 38.1 & $56.87 \%$ & $69.35 \%$ & $65.96 \%$ & $54.36 \%$ & $53.60 \%$ & $56.87 \%$ \\
& 25.4 & $46.53 \%$ & $58.60 \%$ & $56.86 \%$ & $31.16 \%$ & $46.50 \%$ & $46.53 \%$ \\
& 19 & $40.76 \%$ & $51.55 \%$ & $48.83 \%$ & $21.59 \%$ & $41.65 \%$ & $40.76 \%$ \\
& 12.7 & $33.91 \%$ & $42.54 \%$ & $47.78 \%$ & $15.77 \%$ & $17.26 \%$ & $33.91 \%$ \\
& 9.51 & $30.03 \%$ & $36.81 \%$ & $41.16 \%$ & $13.38 \%$ & $14.15 \%$ & $30.03 \%$ \\
& 4.76 & $22.45 \%$ & $27.77 \%$ & $29.17 \%$ & $10.34 \%$ & $9.22 \%$ & $22.45 \%$ \\
& 2.38 & $16.85 \%$ & $21.34 \%$ & $22.32 \%$ & $7.67 \%$ & $5.18 \%$ & $16.85 \%$ \\
& 2 & $15.20 \%$ & $19.95 \%$ & $21.16 \%$ & $7.02 \%$ & $4.36 \%$ & $15.20 \%$ \\
& 1.19 & $11.30 \%$ & $13.34 \%$ & $15.15 \%$ & $4.90 \%$ & $2.25 \%$ & $11.30 \%$ \\
& 0.595 & $5.22 \%$ & $3.52 \%$ & $6.04 \%$ & $2.11 \%$ & $0.77 \%$ & $5.22 \%$ \\
& 0.297 & $1.42 \%$ & $0.39 \%$ & $1.42 \%$ & $0.47 \%$ & $0.17 \%$ & $1.42 \%$ \\
& 0.149 & $0.50 \%$ & $0.08 \%$ & $0.32 \%$ & $0.11 \%$ & $0.05 \%$ & $0.50 \%$ \\
& 0.075 & $0.25 \%$ & $0.04 \%$ & $0.09 \%$ & $0.04 \%$ & $0.02 \%$ & $0.25 \%$ \\
& 0.0625 & $0.22 \%$ & $0.03 \%$ & $0.07 \%$ & $0.03 \%$ & $0.02 \%$ & $0.22 \%$ \\
\hline
\end{tabular}


Table 7. Fines grain size analysis for sediment samples collected for six study sites below Iron Gate Dam.

\begin{tabular}{crrrrrrr}
\hline \multirow{3}{*}{ Boulder } & Grain size & \multicolumn{5}{c}{ Percent passing (fines) } \\
\cline { 2 - 7 } & $(\mathrm{mm})$ & Reach 1 & Reach 2 & Reach 3 & Reach 4 & Reach 5 & Reach 6 \\
\hline \multirow{3}{*}{ Cobbles } & 512 & $100.00 \%$ & $100.00 \%$ & $100.00 \%$ & $100.00 \%$ & $100.00 \%$ & $100.00 \%$ \\
& 362 & $100.00 \%$ & $100.00 \%$ & $100.00 \%$ & $100.00 \%$ & $100.00 \%$ & $100.00 \%$ \\
& 256 & $100.00 \%$ & $100.00 \%$ & $100.00 \%$ & $100.00 \%$ & $100.00 \%$ & $100.00 \%$ \\
& 180 & $100.00 \%$ & $100.00 \%$ & $100.00 \%$ & $100.00 \%$ & $100.00 \%$ & $100.00 \%$ \\
& 128 & $100.00 \%$ & $100.00 \%$ & $100.00 \%$ & $100.00 \%$ & $100.00 \%$ & $100.00 \%$ \\
& 90 & $100.00 \%$ & $100.00 \%$ & $100.00 \%$ & $100.00 \%$ & $100.00 \%$ & $100.00 \%$ \\
Gravel & 64 & $100.00 \%$ & $100.00 \%$ & $100.00 \%$ & $100.00 \%$ & $100.00 \%$ & $100.00 \%$ \\
& 45 & $100.00 \%$ & $100.00 \%$ & $100.00 \%$ & $100.00 \%$ & $100.00 \%$ & $100.00 \%$ \\
& 38.1 & $100.00 \%$ & $100.00 \%$ & $100.00 \%$ & $100.00 \%$ & $100.00 \%$ & $100.00 \%$ \\
& 25.4 & $100.00 \%$ & $100.00 \%$ & $100.00 \%$ & $100.00 \%$ & $100.00 \%$ & $100.00 \%$ \\
& 19 & $100.00 \%$ & $100.00 \%$ & $100.00 \%$ & $100.00 \%$ & $100.00 \%$ & $100.00 \%$ \\
& 12.7 & $100.00 \%$ & $100.00 \%$ & $100.00 \%$ & $99.70 \%$ & $99.05 \%$ & $99.05 \%$ \\
& 9.51 & $100.00 \%$ & $100.00 \%$ & $100.00 \%$ & $99.59 \%$ & $95.71 \%$ & $95.71 \%$ \\
& 4.76 & $100.00 \%$ & $100.00 \%$ & $100.00 \%$ & $99.53 \%$ & $93.58 \%$ & $93.58 \%$ \\
& 2.38 & $100.00 \%$ & $100.00 \%$ & $100.00 \%$ & $99.45 \%$ & $87.28 \%$ & $87.28 \%$ \\
& 2 & $93.87 \%$ & $97.11 \%$ & $100.00 \%$ & $99.44 \%$ & $85.00 \%$ & $85.00 \%$ \\
& 1.19 & $91.52 \%$ & $89.78 \%$ & $99.93 \%$ & $99.35 \%$ & $74.76 \%$ & $74.76 \%$ \\
& 0.595 & $74.49 \%$ & $68.99 \%$ & $98.82 \%$ & $98.57 \%$ & $53.98 \%$ & $53.98 \%$ \\
& 0.297 & $27.47 \%$ & $27.10 \%$ & $66.33 \%$ & $83.34 \%$ & $27.11 \%$ & $27.11 \%$ \\
& 0.149 & $4.92 \%$ & $3.05 \%$ & $13.56 \%$ & $36.08 \%$ & $9.54 \%$ & $9.54 \%$ \\
& 0.075 & $0.35 \%$ & $0.15 \%$ & $0.51 \%$ & $8.14 \%$ & $2.35 \%$ & $2.35 \%$ \\
& 0.0625 & $0.08 \%$ & $0.07 \%$ & $0.10 \%$ & $5.23 \%$ & $1.76 \%$ & $1.76 \%$ \\
\hline
\end{tabular}


Publishing support provided by: Denver Publishing Service Center

For more information concerning this publication, contact: Center Director, USGS Fort Collins Science Center

2150 Centre Ave., Bldg. C

Fort Collins, CO 80526-8118

(970)226-9398

Or visit the Fort Collins Science Center Web site at: http://www.fort.usgs.gov/ 